\title{
A Place to Rest Your (Burnt) Bones? Mortuary Houses in Early Anglo-Saxon England
}

\author{
Kathryn Meyers Emery \& Howard Williams \\ Meyers Emery, K. \& Williams, H. (2017): A Place to Rest Your (Burnt) Bones? Mortuary \\ Houses in Early Anglo-Saxon England, Archaeological Journal, DOI: \\ 10.1080/00665983.2017.1366704
}

This article presents a fresh interpretation of square and rectangular mortuary structures found in association with deposits of cremated material and cremation burials in a range of early Anglo-Saxon (fifth-/sixth-century AD) cemeteries across southern and eastern England. Responding to a recent argument that they could be traces of pyre structures, a range of ethnographic analogies are drawn upon, and the full-range of archaeological evidence is synthesized, to re-affirm and extend their interpretation as unburned mortuary structures. Three interleaving significances are proposed: (i) demarcating the burial place of specific individuals or groups from the rest of the cemeterypopulation, (ii) operating as 'columbaria' for the above-ground storage of the cremated dead (i.e.not just to demarcate cremation burials), and (iii) providing key nodes of commemoration between funerals as the structures were built, used, repaired and eventually decayed within cemeteries. The article proposes that timber 'mortuary houses' reveal that groups in early Anglo-Saxon England perceived their cemeteries in relation to contemporary settlement architectures, with some groups constructing and maintaining miniaturized canopied buildings to store and display the cremated remains of the dead.

\section{INTRODUCTION}

In the study of cremation practices in early Anglo-Saxon England, fresh discoveries and recent analyses have facilitated the investigation of both key themes and patterns of variability in the provision of cinerary urn form and decoration, the deposition of pyregoods, the addition of grave-goods following cremation, and the analysis of the burnt human and animal bone (Richards 1987; McKinley 1994; Bond 1996; Ravn 2003; Williams 2011a; 2014; 2015a and b; Nugent and Williams 2012; Squires 2012; 2013; 2017; Hills and Lucy 2013; Nugent 2017). This work has also enriched understanding of the varied relationships between cremation and inhumation graves (Williams 2002; 2015a; Nugent 2017; Squires 2017). However, the inevitable focus on below-ground contexts given that most cemeteries have been partially excavated and subject to medieval and post-medieval disturbance and truncation - risks creating a two-dimensional impression of cremation practice. Monuments and architectures in cemeteries are frequently regarded as incidental or supplementary evidence at best in the interpretation of early Anglo-Saxon cremation practices. The inevitable foci of investigation have been burnt bones, artefacts and urns (e.g. Leahy 2007; Hills and Lucy 2013, 267-69; Williams 2014). Traces of structures tend to be reported on in an anecdotal fashion within cemetery reports and rarely integrated into interpretative syntheses of early medieval death, memory and society. Indeed, discussions of early Anglo-Saxon mortuary monumentality have, for over three decades, exclusively and reductively focused 
upon a contrast between 'flat-grave' cemeteries and increasing evidence of mound building associated with the emergence of early medieval kingdoms in the late sixth and seventh century (Shephard 1979; Carver 2005; Hills and Lucy 2013, 271; Fern 2015). This contrast is important, but it has equally drawn attention away from the complexity and variability of mortuary architectures within fifth/sixth-century AD cemeteries. This situation means that, while it is now recognized that early Anglo-Saxon mortuary

ceremonies were multi-staged and multi-locale spatial-temporal ritual performances in which burning the body was but one option within a range of procedures leading to either cremation or inhumation (e.g. Williams 2004; 2006; 2014; Nugent 2017), evidence for above-ground structures has escaped detailed attention and interpretation.

This article attempts to address how we consider monumentality in relation to early AngloSaxon cremation practices, aiming to redress the imbalance of recent work by exploring the strong evidential and analogous grounds for the importance of timber buildings for marking and enclosing selected cremation deposits. A range of cemetery excavations show that the construction, use, refurbishing and decay of relatively modest above-ground timber mortuary structures was an important element for communities deploying cremation as a disposal method. These structures may have affected how the early AngloSaxon cremated dead were mourned, commemorated and perceived. Moreover, this evidence challenges a simplistic association between the scale of a single type of monument - such as earth-built mounds - and the social status of those mourned and mourning. The study simultaneously contributes to debates regarding the clear differences, as well as similarities, between broadly contemporaneous early Anglo-Saxon cremation and inhumation practices (cf. Nugent 2017; Squires 2017).

We bring together for the first time the range of known archaeological evidence for square and rectangular mortuary structures associated with cremation practices in early AngloSaxon cremation England, proposing that these timber architectures might have possessed interleaving mnemonic significances in the cremation process (see also Williams 2006) and the spatial organization of cemeteries (for a broader discussion, see Semple and Williams 2015), including the power of cremation to facilitate the integration of the dead collectively into relatively ephemeral and small-scale architectures (for a theoretical framework, see Wessman and Williams 2017). In pursuing this evidence, the article also advocates the potential of ethnographic evidence for offering insights into early Anglo-Saxon mortuary practice (an argument explored in greater detail by Williams 2016). Our study functions as a response to a recent and important discussion of the Tranmer House, Bromeswell (Suffolk), early Anglo-Saxon mixed-rite (bi-ritual) cemetery by Chris Fern (2015). Fern has argued, based on the evidence of a single four-post structure with cremated material in the fill of three posts, that 'mortuary houses' elsewhere might represent traces of funeral pyres.

Suggesting they were most likely built following the collection of ashes from pyres constructed on that spot, or from elsewhere, three potentially interrelated mnemonic roles for these relatively modest, above-ground structures are proposed:

(1) marking the graves of particular groups or individuals;

(2) staging the post-cremation examination and treatment of ashes, including the recycling of artefacts retrieved from the pyre; 
(3) providing loci for post-funeral commemorative practices through their maintenance, repair, refurbishment and eventual decay in the months and years of their use, thus attracting sequences of graves in their vicinity.

Linking together these themes, we contextualize the evidence with research on possible pagan cult buildings and the performance and mortuary dimensions of early Anglo-Saxon domestic architecture, in which these structures have surprisingly been omitted (Blair 1995; Hamerow 2012; Soffield 2015). We propose that the storage or 'housing' of the cremated dead was a key metaphor by which death and the dead were perceived - a theme more extensively explored by other researchers for the Scandinavian later Iron Age (Eriksen 2013; 2016; Gardeła 2015). The early Anglo-Saxon cremated dead were constituted in collective dwellings within cemeteries, thus miniaturizing and citing contemporary settlement architectures when stored and displayed.

\section{MONUMENTS FOR THE EARLY ANGLO-SAXON CREMATED DEAD}

Given that cremation in early Anglo-Saxon England involved the open-air fiery dissolution of the dressed cadaver(s), frequently together with a range of vessels, artefacts, food offerings and animal sacrifices (McKinley 1994; Bond 1996; Squires 2012; 2013), it is now well-established for archaeologists to recognize the performative and material investment involved. This interpretation of cremation can, however, misleadingly give the impression that cremation tended towards being counter-monumental (see Williams et al. 2017). Early Anglo-Saxon cremation burials are often inserted in small and shallow pits, frequently in close proximity to each other, and sometimes in features containing pairs or clusters of cinerary urns. Therefore, cremation burial is likely to be under-represented on many cemetery sites affected by later disturbance and truncation in which inhumation graves both larger and deeper - are more likely to be found. Moreover, relatively superficial features that do not cut into the underlying subsoil might be readily missed in all but the most careful, open-area, excavations. Certainly, especially since many early Anglo-Saxon cemeteries were located at places with complex sequences of earlier and later activity (e.g. Williams 1997), it is commonly difficult for archaeologists to demonstrate conclusively from excavated evidence that features which might represent above-ground structures were indeed contemporaneous with graves, rather than evidence of far earlier or later practices (e.g. McKinley 2003, 13-18).

For this host of reasons, identifying and investigating cremation burials, and discerning clear evidence for their above-ground elaboration, are challenges for field archaeologists. Hence, it is all too easy to underestimate the importance of cremation's above mortuary ground funerary structures, and quantifying their prevalence with any certainty is likely to stretch the evidence too far. Therefore, when cemeteries with cremation burials reveal no hint as to whether they were marked or unmarked, this cannot be taken at face value (e.g. Kinsley 1989; Timby 1993; Leahy 2007). Thanks in particular to the last four decades which have seen a range of open-area excavations by commercial archaeologists that have, because of their scale and rigorous techniques applied, even when exploring disturbed and truncated sites, produced a range of new evidence to reveal architectural dimensions to early Anglo-Saxon cremation practice (see Hills and Lucy 2003, 267-70). 
Early Anglo-Saxon cemeteries have produced positive evidence of features which suggest the former presence of above-ground structures associated with inhumation graves (e.g. Hogarth 1973; Hills et al. 1984; Hills and Lucy 2003, 270-71). Ring-ditches might denote the former presence of burial mounds over cremation graves, as identified at (for example) Portway Andover (Hampshire), Springfield Lyons (Essex), Collingbourne Ducis (Wiltshire), and Tranmer House, Bromeswell (Suffolk) (Cook and Dacre 1985; Tyler and Major 2005; Egging Dinwiddy and Stoodley 2015, 8, 146; Fern 2015). In turn, since ring-ditches are in no way necessary to raise modest mounds over burials (since surface material might be scraped up from a wider area), it is plausible that these recorded instances are the veritable tip of an iceberg of above-ground mounds and structures that rarely survive. Namely, many other, if not most, early Anglo-Saxon cremation pits or groups of buried cinerary urns might have once been marked by mounds or cairns. This is supported by very rare occasions where antiquarian records and surviving earthworks indicate the presence of mounds over cremation burials (e.g. Meaney 1964; Saunders 1980).

Meanwhile, although later in date and exceptional in their scale, the unambiguous evidence that late sixth and early seventh-century high-status cremation burials beneath barrows at (for example) Asthall (Oxfordshire) and Brightwell Heath (Suffolk), might be best seen as emerging from a broader tradition of mounds raised over cremation burials (Dickinson and Speake 1992; Carver 2005). Likewise, the princely burial ground of Sutton Hoo, Suffolk, despite still being characterized by the exceptional (and perhaps late in the burial sequence) boat inhumations associated with Mounds 1 and 2, is demonstrably a site where most large mounds covered richly furnished cremation graves (Carver 2005). This is important to emphasize, since so often the narratives regarding monumentality have been misleadingly configured around rich chambered inhumation graves like Taplow, Prittlewell and Sutton Hoo Mound 1 (e.g. Williams 2011b).

Returning to more modest, fifth-/sixth-century graves, at Spong Hill (Norfolk), flints were placed over graves which might be residual traces of cairns piled over either single cremation pits or clusters of cinerary urns (Hills and Lucy 2013). Therefore, we can anticipate that both inhumation graves and cremation burials in early Anglo-Saxon England perhaps never constituted 'flat graves'. Instead, our default appreciation should be that individual burials and/or groups of graves were surmounted or surrounded by one or more type of mound or structure.

\section{TIMBER POSTS AND POST-LINES}

In addition to these traces of mounds and cairns, there are also indications of post-holes, post-lines and gullies from early Anglo-Saxon cemeteries, many associated with cremation graves. Some of these may have been parts of memorial structures used to display, mark and contain the cremated dead (reviewed by Wessman and Williams 2017). At Alwalton (Cambridgeshire), for example, a series of five post-holes was found around three cremation burials (1293, 1257 and 1266), and may represent either a screen or individual grave markers (Gibson 2007). Similar evidence comes from the Portway Andover (Hampshire) cemetery, where lines of posts were identified in the middle of cemetery. These were found in close proximity to a series of cremation burials (Cook and Dacre 1985; see also Down and Welch 1990). One possible explanation is that such structures were utilized for the display of cremated human remains on platforms, the tops of posts, or 
suspended from them in bags. While their function is by no means certain, we must entertain that cremation afforded the opportunity for the storage of the cremated dead above as well as below ground in pits or graves within early Anglo-Saxon cemeteries (see also Williams 2016), a point to which we shall return in this article. If this were the case, we might be significantly under-estimating the proportion of early Anglo-Saxon burying populations represented in the archaeological record from graves alone.

It is important to mention that this range of evidence fits a pattern of late fifth-, sixth and seventh-century inhumation graves elsewhere found in association with features including ring-ditches and rectangular gullied features and post-hole arrangements surrounding inhumation graves (as at Broadstairs, Kent: Hogarth 1973) or adjacent to them (as a Lyminge, Kent). Blair (1995, 8-10) refers to these as 'category C: small square-planed ditched enclosures associated with graves'. Meanwhile, at the Cemetery II at Mucking (Essex) and the Street House (North Yorkshire) cemeteries both contained SFBs (sunkenfeatured buildings: commonly regarded as multi-purpose ancillary structures on settlements), which may have been used as mortuaries contemporaneous with, and located within, cemeteries (Hamerow 2012, 121). The Spong Hill cemetery (where cremation dominated) produced a rectangular building ( $\mathrm{PG}_{3}$ ) adjacent to cremation burials, although a chronological relationship was unclear (Hills and Lucy 2013, 267). Therefore, while it is not the case that cremation burials were exclusively connected to these range of structures, but it is important to assert that cremation was integral to the range of early Anglo-Saxon cemetery architectures when and where archaeologists can discern them.

\section{TIMBER 'MORTUARY HOUSES'}

Amidst this evidence for mounds, cairns, posts and post-lines, a distinctive range of square and rectangular structures have been increasingly found in early Anglo-Saxon cemeteries in recent decades (Illus. 1; Table 1). Many are made of four- and five-posts, some by linear gullies (which presumably contained beam slots), and rarer still by posts with connecting gullies/beam slots (one at Apple Down (Down and Welch 1990), one at Collingbourne Ducis (Egging Dinwiddy and Stoodley 2015)). Some lack surviving association with human remains, a few appear connected to inhumation graves, but most are found with deposits of cremated material. They were first discussed in print in the context of the Alton (Hampshire) cemetery report (Evison 1988) where two rectangular trenched structures were identified. Evison $(1988,35-6)$ countered the possibility that they were traces of pyre structures given the absence of either a cremation layer or indications of burnt posts (Illus. 2). She suggested they were instead tombs raised to 'contain the remains from the funeral pyre which had been burned elsewhere'. 


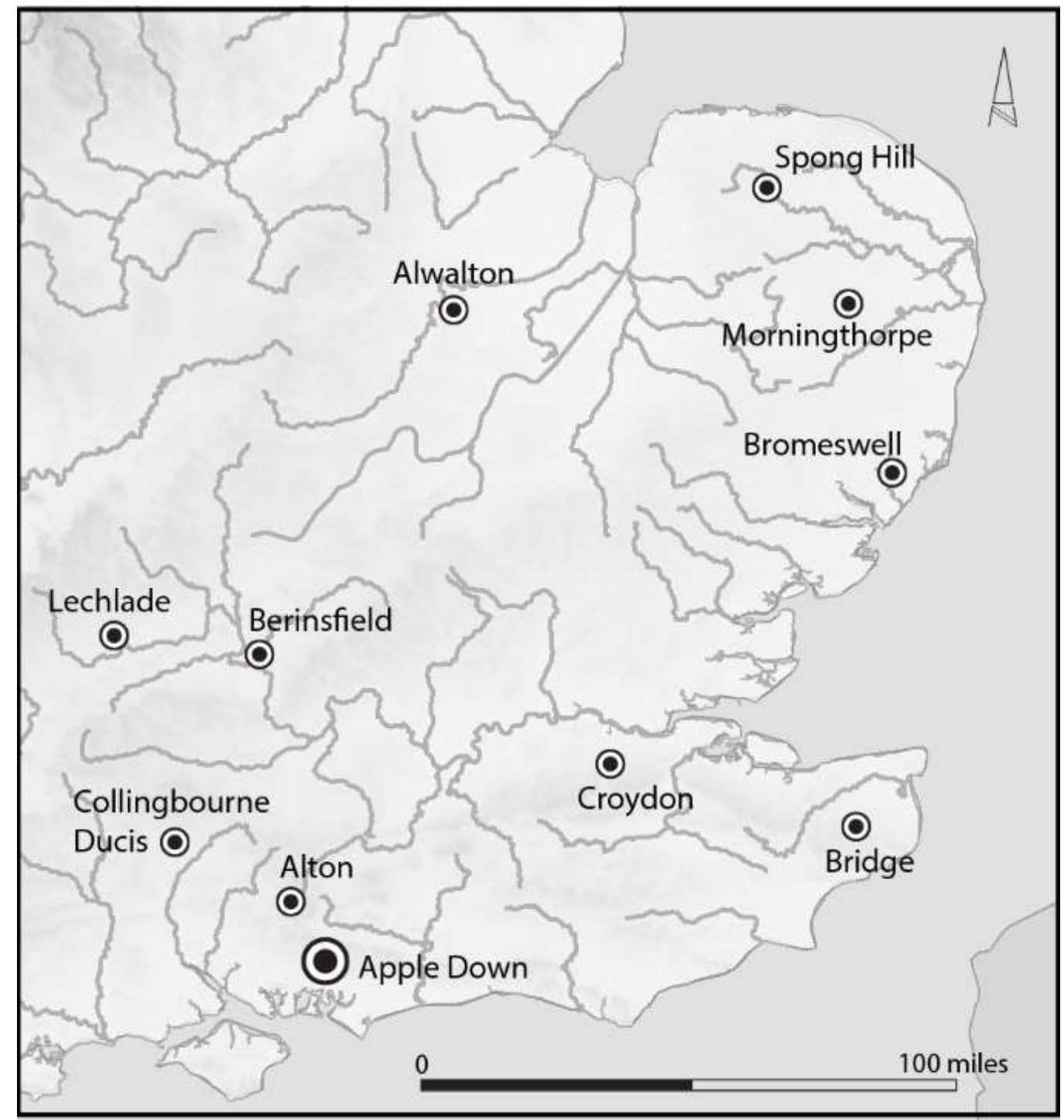

Illus. 1 Map of sites mentioned in this article. Drawn by Howard Williams. 
Table 1 Early Anglo-Saxon cemeteries with timber 'mortuary houses'

\begin{tabular}{|c|c|c|c|c|c|c|c|}
\hline CEMETERY & PERIOD & TYPE & CREMATION & $\begin{array}{l}\text { INHUMATIO } \\
\mathrm{N}\end{array}$ & $\begin{array}{l}\text { MORTUAR } \\
\text { Y HOUSES }\end{array}$ & REFERENCES & ILLUS. \\
\hline $\begin{array}{l}\text { Alton } \\
\text { (Hampshire) }\end{array}$ & Late $5^{\text {th }}-6^{\text {th }}$ & $\begin{array}{l}\text { Bi-ritual } \\
\text { (Mixed-rite) }\end{array}$ & 30 & 25 & 2 & Evison 1988 & 2 \\
\hline $\begin{array}{l}\text { Alwalton } \\
\text { (Cambridgeshire) }\end{array}$ & $5^{\text {th }}$-early $7^{\text {th }}$ & $\begin{array}{l}\text { Bi-ritual } \\
\text { (Mixed-rite) }\end{array}$ & 30 & 34 & 1 & Gibson 2007 & 7 \\
\hline $\begin{array}{l}\text { Apple Down } \\
\text { (Sussex) }\end{array}$ & Late $5^{\text {th }}-7^{\text {th }}$ & $\begin{array}{l}\text { Bi-ritual } \\
\text { (Mixed-rite) }\end{array}$ & 138 & 121 & 31 & $\begin{array}{l}\text { Down and } \\
\text { Welch } 1990\end{array}$ & 3 \\
\hline $\begin{array}{l}\text { Berinsfield } \\
\text { (Oxfordshire) }\end{array}$ & Late $5^{\text {th }}-7^{\text {th }}$ & $\begin{array}{l}\text { Bi-ritual } \\
\text { (Mixed-rite) }\end{array}$ & 2 & 103 & 1 & $\begin{array}{l}\text { Boyle et al. } \\
1995\end{array}$ & 8 \\
\hline $\begin{array}{l}\text { Butler's Field, } \\
\text { Lechlade } \\
\text { (Gloucestershire) }\end{array}$ & $6^{\text {th }}-7^{\text {th }}$ & $\begin{array}{l}\text { Bi-ritual } \\
\text { (Mixed-rite) }\end{array}$ & 32 & 217 & 2 & $\begin{array}{l}\text { Boyle et al. } \\
\text { 1998; Boyle } \\
\text { et al. } 2011\end{array}$ & 9 \\
\hline $\begin{array}{l}\text { Collingbourne } \\
\text { Ducis (Wiltshire) }\end{array}$ & Late $5^{\text {th }}-7^{\text {th }}$ & $\begin{array}{l}\text { Predominantly } \\
\text { inhumation }\end{array}$ & 4 & 82 & 2 & $\begin{array}{l}\text { Egging } \\
\text { Dinwiddy and } \\
\text { Stoodley } \\
2015\end{array}$ & 11 \\
\hline Croydon (Surrey) & $5^{\text {th }}-6^{\text {th }}$ & $\begin{array}{l}\text { Bi-ritual } \\
\text { (Mixed-rite) }\end{array}$ & 5 & 41 & 1 & $\begin{array}{l}\text { McKinley } \\
2003\end{array}$ & 12 \\
\hline $\begin{array}{l}\text { Morningthorpe } \\
\text { (Norfolk) }\end{array}$ & $6^{\text {th }}$ & $\begin{array}{l}\text { Bi-ritual } \\
\text { (Mixed-rite) }\end{array}$ & 9 & 365 & 1 & $\begin{array}{l}\text { Green et al. } \\
1987\end{array}$ & \\
\hline $\begin{array}{l}\text { Spong Hill } \\
\text { (Norfolk) }\end{array}$ & $5^{\text {th }}-6^{\text {th }}$ & $\begin{array}{l}\text { Predominantly } \\
\text { cremation }\end{array}$ & 2259 & 57 & $1-3$ & $\begin{array}{l}\text { Hills et al. } \\
1984 ; \text { Hills } \\
\text { and Lucy } \\
2013\end{array}$ & \\
\hline Star Hill (Kent) & $5^{\text {th }}-7^{\text {th }}$ & $\begin{array}{l}\text { Predominantly } \\
\text { inhumation }\end{array}$ & 3 & 90 & 1 & $\begin{array}{l}\text { Wilkinson } \\
2008\end{array}$ & \\
\hline $\begin{array}{l}\text { Tranmer House, } \\
\text { Bromeswell } \\
\text { (Suffolk) }\end{array}$ & $6^{\text {th }}$ & $\begin{array}{l}\text { Bi-ritual } \\
\text { (Mixed-rite) }\end{array}$ & 13 & 18 & 1 & Fern 2015 & 6 \\
\hline
\end{tabular}

Soon after, a staggering thirty-one structures were reported on, many associated with cremation deposits, at the long-running sixth-/seventh-century cemetery at Apple Down (West Sussex) (Down and Welch 1990). This was the largest number of 'mortuary houses' the only site producing more than two, and it might be distinctive because cremation here could have persisted into the seventh century (ibid., 108). Most were square, or rectangular, and comprise of four posts, although some (eleven) had a fifth post/burial at their centre (Illus. 3). Among the Apple Down four- and five-post arrangements, one was an exception - Structure 10 - because it consisted of four posts and a fifth post on the periphery (Down and Welch 1990, 27). The Apple Down structures varied in size from $1 \mathrm{~m}$ square to 2.7 by 2.5 $\mathrm{m}$ wide. Apple Down also revealed nineteen ring-ditches associated with cremation burials, some circular, penannular and oval ring-ditches. Evidently there was a broader spectrum of above-ground structures deployed during the life-history of the burial ground. Two of the ring-ditches surrounded four-post structures (3 and 20) (Down and Welch 1990, 25-33; 2027). Significantly, there were two further structures associated with inhumation graves, illustrating again that this was a dimension of mortuary practice not exclusively, connected to the treatment of the cremated dead. Striking illustrations by Max Wholey accompanied the site report. While the images afford a somewhat atemporal scenes, with the cemeterywide image showing all the structures in place, well-maintained and contemporaneously in 
use, his art effectively gives a sense of the impact of relatively modest structures on the appearance of the cemetery in a chalk downland environment (Illus. 4). As well as a cemetery scene, Wholey drew two possible scenarios for the construction method of these structures in the published report (Illus. 5).

Subsequent discoveries and publications reveal that the Alton and Apple Down buildings are far from exceptional, even if the number found at Apple Down is currently unparalleled. At Spong Hill (Norfolk), one six-post structure, and one four-or-five post structure (PG5) might also mark mortuary structures. They were immediately west of a semi-circular arc of cremation burials open on the west known as 'the 'north-west setting' (Hills and Lucy 2013, 267). Another possible example is Structure 581 at Spong Hill: a rectangular shallow ditch not surrounding a grave but cutting through an earlier inhumation grave and cut by later cremation burials (Hills and Lucy 2013, 269-70). Likewise, a rectangular structure at the Morningthorpe cemetery was within an area of cremation burials but notably it lacked a single central interment (Green et al. 1987). There are also single four-post structures from Alwalton (Cambridgeshire) cemetery, and the cemetery to the immediate north of the later 'princely' mounds at Sutton Hoo: Tranmer House, Bromesewell (Suffolk) (Fern 2015). To the authors' knowledge, no examples have been discerned in the East Midlands or north of the Humber, suggesting either that this was a relatively rare practice in the 'Anglian' areas where cremation predominated (cf. Williams 2002), or else the quality of archaeological investigations has not been such to regularly reveal these ephemeral structures.

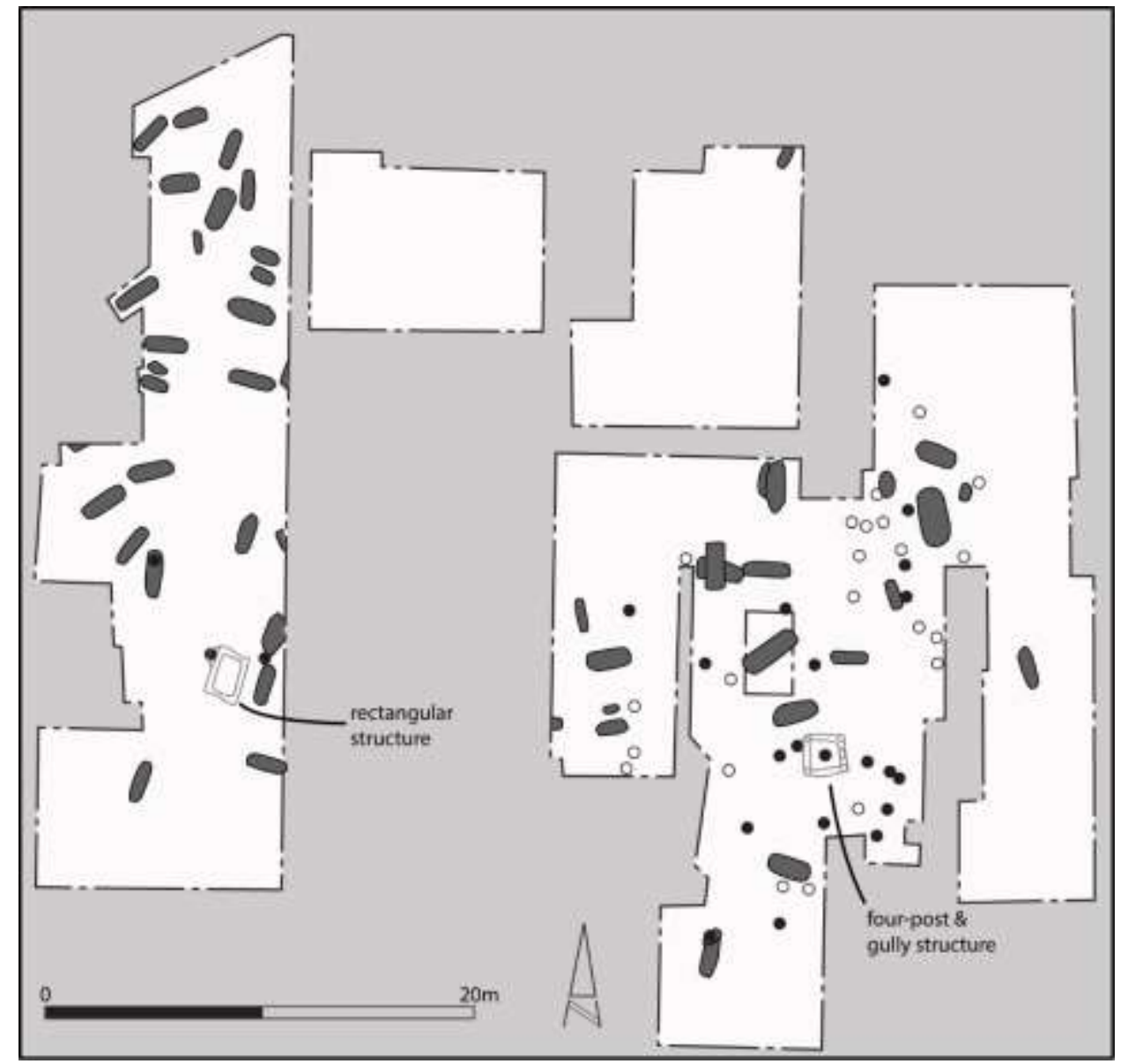

Illus. 2 Plan of the Alton (Hampshire) cemetery. Redrawn after Evison 1988 by Howard Williams 


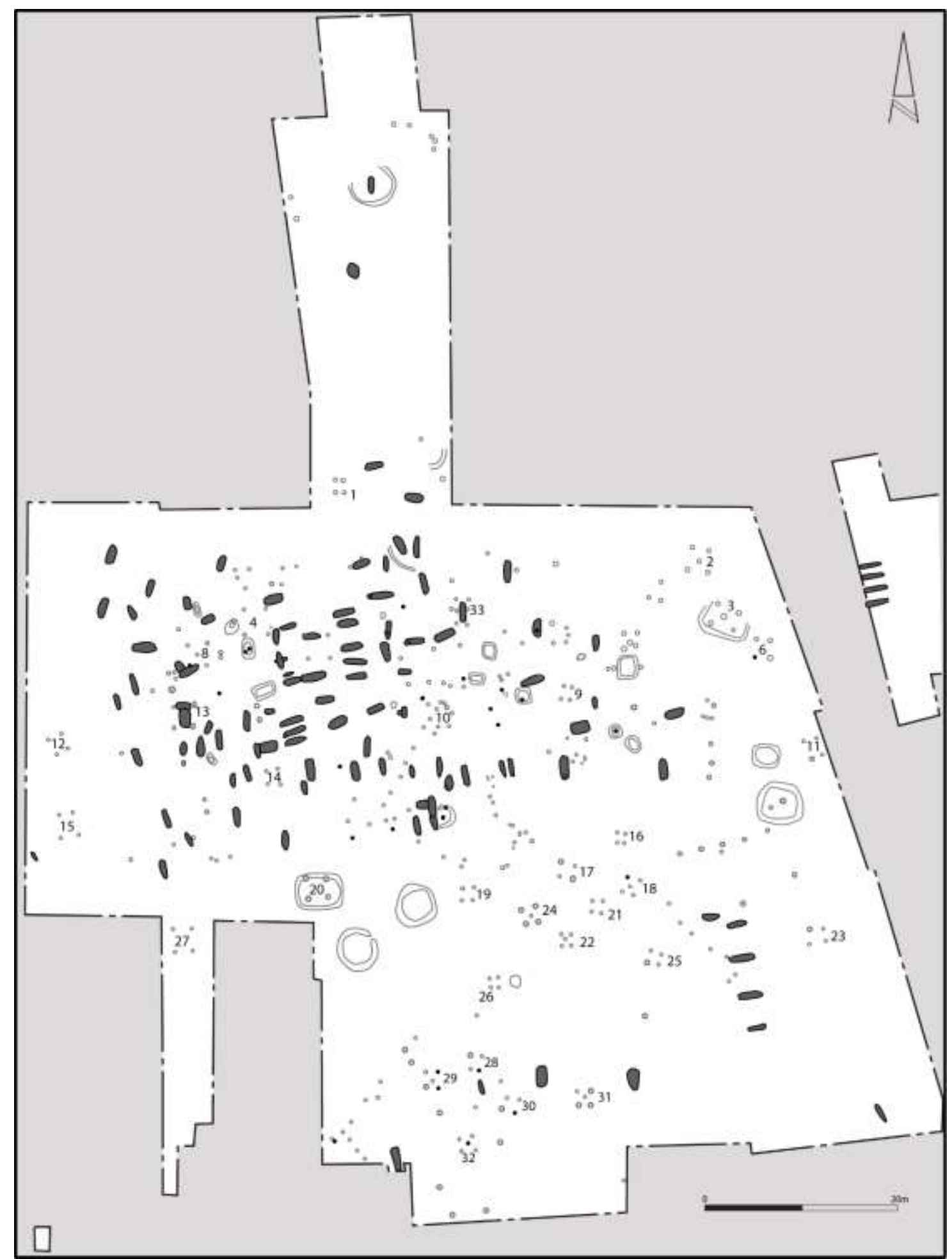

Illus. 3 Plan of graves and structures at Apple Down, West Sussex. Redrawn after Down and Welch 1990 by Howard Williams 


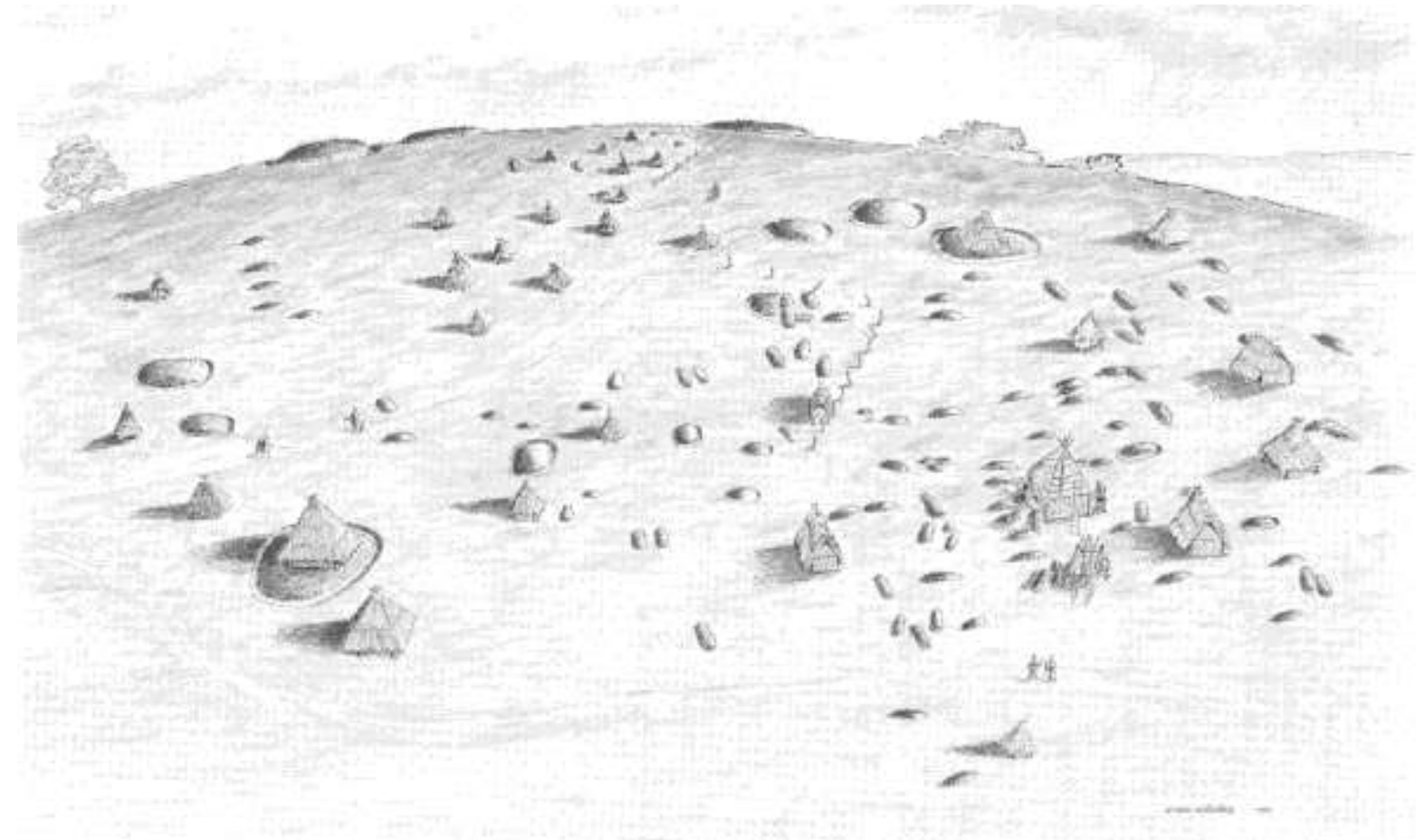

Illus. 4 Artist's reconstruction of Apple Down by Max Wholey, 1989. (Reproduced by permission of Chichester District Council)
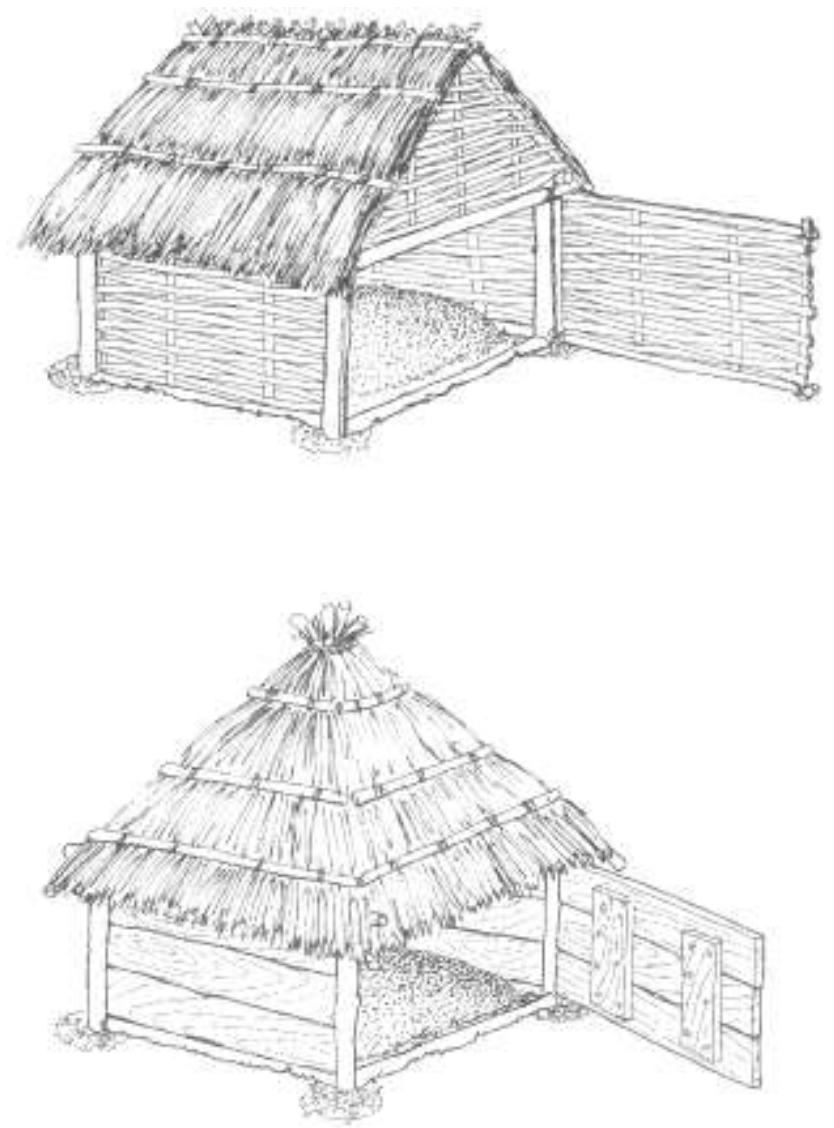

Illus. 5 Artist's reconstructions of timber mortuary houses at Apple Down by Max Wholey, 1989. (Reproduced by permission of Chichester District Council) 
Joining Alton and Apple Down, further single instances have been found in 'Saxon' regions (central and southern England) - including among graves in the Berinsfield (Oxfordshire) and Lechlade (Gloucestershire) cemeteries of the Upper Thames region, and Croydon (Greater London, formerly Surrey (McKinley 2003). A case is also known from Star Hill, east Kent, from the edge of an inhumation cemetery and in a region where cremation is rare (Wilkinson 2008; Illus. 1, Table 1; see Williams 2002). The Lechlade (Gloucestershire) and the Collingbourne Ducis (Wiltshire) cemeteries are significant for producing two structures each (Boyle et al. 2011; Egging Dinwiddy and Stoodley 2015).

While unlikely to relate to coherent cultural predilections, the geographical spread of examples supports previous work which has shown an apparent distinction between the technology and significance of cremation within a core area in eastern England (East Yorkshire, East Midlands and East Anglia) where large cremation cemeteries of the fifth and early sixth centuries have been found, and a broader distribution of cremation practices operating alongside inhumation cemeteries, evidenced by 'mixed-rite' cemeteries across central and southern England (Squires 2013; Williams 2002; 2015b; see also Hills and Lucy 2013). Alternatively, especially in the light of the Spong Hill evidence (Hills and Lucy 2013, 267-72), this might simply represent how it is far more difficult to discern these structures in larger cemeteries with many hundreds of cremation burials associated with undated pits and trenches.

The mortuary structures in question are difficult to date (e.g. McKinley 2003, 13-18), although some have been directly associated with the late fifth/sixth centuries from artefacts associated with cremation burials, whilst some might be seventh century, or endured into the seventh century, given their spatial influence on inhumation graves around them (e.g. Egging Dinwiddy and Stoodley 2015, 8). These structures might be relatively short-lived in terms of the cemetery's full duration, however, they may still have been enduring structures in the months, years and decades after their construction and thus an important part of the remembering and forgetting of the deceased and his/her network of social relationships (cf. Williams 2006). Their ephemeral nature has been proposed given that a later cremation burials was noticed overlying the structure from Spong Hill (Hills et al. 1984, 12). Yet at Apple Down, the excavators discerned possible evidence of repair to some structures, namely the evidence of cremated remains included in posts (Down and Welch 1990, 29) and at Alton the structures were found associated with multiple cremation deposits. Unless these were all foundation deposits associated with the initial erection of the structures during the burning of pyres subsequently lost to truncation, they indicate that these building were associated with more than one funeral and/or refurbished between phases of use (Down and Welch 1990, 29). Stoodley $(2015,146)$ argues the same for the group of features (1268) comprising four-post structure with connecting gullies from Collingbourne Ducis. It is notable that of the thirty-one Apple Down structures, only one (4) was cut by a larger inhumation grave (86), suggesting they retained a presence in the cemetery space for some time. Still, there are other examples cut by a later, sixth-century, inhumation graves, as with structure 1268 at Collingbourne Ducis (Egging Dinwiddy and Stoodley 2015, 9; Stoodley 2015, 146) as does the four-post structure from Lechlade (Boyle 2011, 159-160), suggesting that their maintenance could end within cemeteries' duration of use. Sadly, precise details of the appearance, composition, duration, repair or deliberate destruction elude archaeologists at present. Still, it remains a 
hypothesis that these were moderately enduring structures left to slowly decay: creating a tempo for remembering and forgetting those interred in association with these structures (see also Wessman and Williams 2017).

Following Evison (1988) and Down and Welch (1990), a clear consensus has developed that these are indeed post-burial 'mortuary houses' or 'shrines', rather than pyres, constructed to receive one or more deposits of cremated human remains and perhaps other commemorative practices (e.g. McKinley 2003; Hills and Lucy 2013, 271; McKinley 2015, 99; Stoodley 2015). However, to date there has been no ystematic discussion of the material or extension and theorized interpretation of the evidence.

In contrast, this tradition of interpretation has recently been challenged by Chris Fern (2015), who interprets a four-post structure surrounding a cremation burial at the Tranmer House cemetery (Suffolk) as a pyre structure, with truncation explaining the absence of conclusive evidence for a cremation pyre associated with this feature. Fern is right to raise this possibility and he tentatively suggests the extension of this argument to other cemeteries, although this argument is not fully executed within the context of his cemetery report. Therefore, responding to Fern's important discussion of a widely neglected dimension of early Anglo-Saxon mortuary practice, the time is ripe to revisit the evidence and reiterate the most likely interpretation of these structures. We wish to explore three dimensions to these structures further.

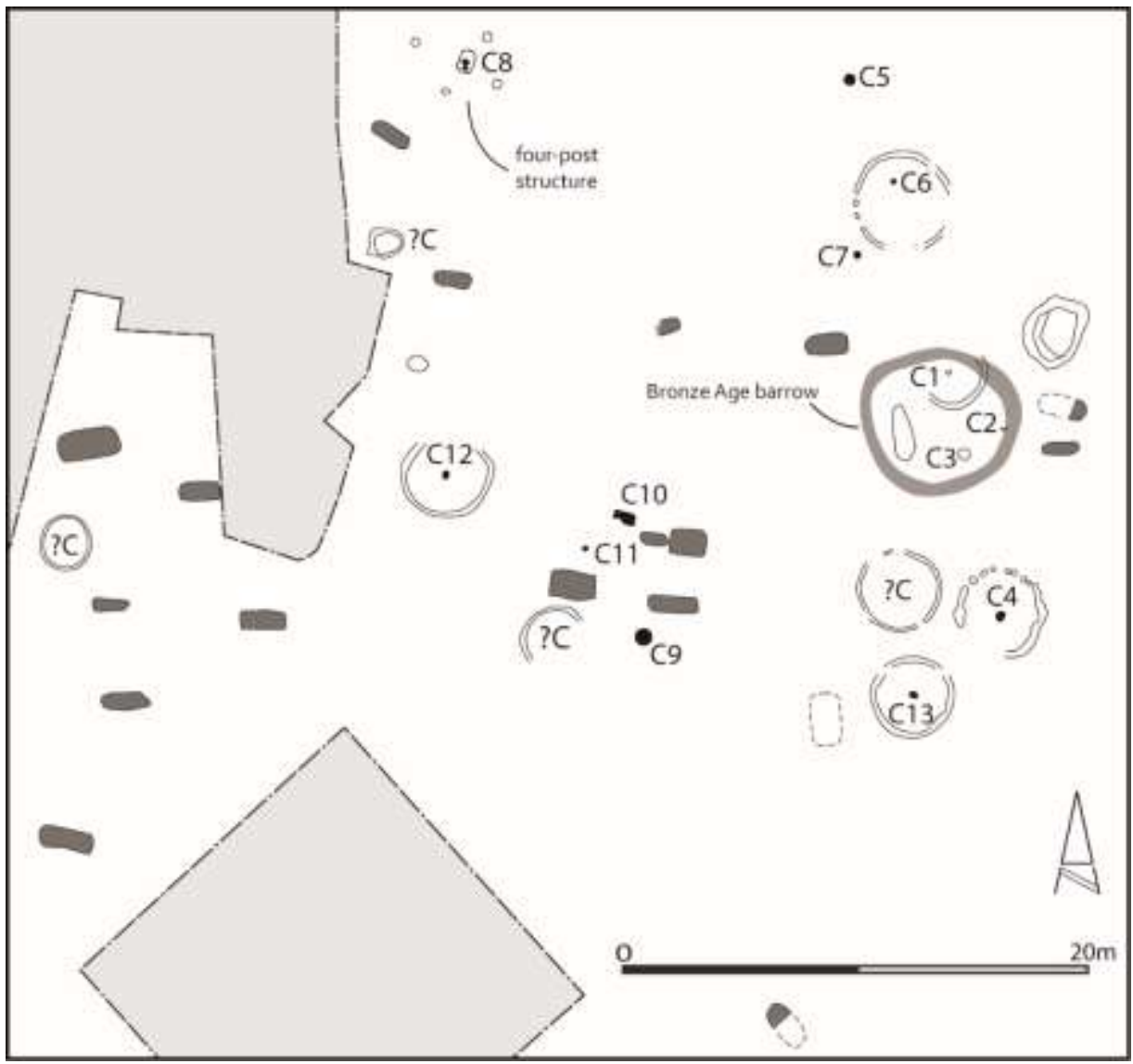

Illus. 6 Plan of the Tranmer House, Bromeswell (Suffolk) cemetery showing the four-post structure around cremation 8 . Redrawn after Fern 2015 by Howard Williams 


\section{MARKING OUT PARTICULAR INDIVIDUALS OR GROUPS}

Notwithstanding the difficulty of seeing isolated examples of four-post structures as full evidence of their prevalence on any individual, partially investigated, cemetery, there are now a range of instances where these structures appear to have been isolated and respected within the cemetery organization. We wish to focus on four examples.

\section{Tranmer House}

At the Tranmer House cemetery (Illus. 6), a sixth-century exceptionally rich cremation burial (8) contained two vessels - a bronze hanging bowl and ceramic pot. This grave was surrounded by four small pits. Three included small amounts of cremated bone in charcoalrich fills, object fragments and metal globules, including fragments that link these deposits to the main burial. The inference, despite the lack of evidence of a broader scatter of burnt material or a burnt earth layer, was that these posts represent a pyre around $2 \mathrm{~m}$ by $3.5 \mathrm{~m}$ in size. Some of the cremated bone from the post-holes was 'worn and chalky'. The association of post-holes with a possible cremation pyre has been suggested for the highstatus barrow-burial at Asthall (Oxfordshire), but this was based on small-scale early twentieth-century excavations that did not fully reveal the extent of the feature (Speake and Dickinson 1992). Instead, Fern $(2015,201)$ moves on to Continental evidence for in situ pyres associated with demonstrably burned four-post structures. The fact that the postholes are not aligned in a rectangle or square, but an off-set trapezoid, might hint that we are indeed looking at something different from the mortuary structures discussed elsewhere. Yet while the lack of a fired surface might be explained by later truncation, it is equally possible that the pits were dug for uprights after the cremation and associated with the burial event. In this regard, it is worth questioning why there was so little pyre material in the grave-fill had it been cut through a fresh pyre layer (Fern 2015, 44)?

The evidence instead might support an interpretation of a pyre-site situated close by to the cremation burial, with the burial inserted centrally within a post-burial four-post structure that only when demolished became filled with (by that time) worn burnt material. Alternatively, if the posts do represent a mortuary house, its post-holes contain material from cremation burials placed upon or above ground level and entering into the post-holes after the building had rotted and collapsed. Notwithstanding Fern's (2015) interpretation of the Tranmer House four-post structure as a pyre - and admittedly its trapezoidal shape is in any case distinctive from most other examples - it is clear that this feature was not typical at this cemetery, let alone those described above and found elsewhere. Instead, the postholes were unique for the burial ground and marked the wealthiest cremation burial. Demonstrably, no ring-ditch surrounded this grave, thus the grave was different in its internal composition and external form from the other cremation and inhumation graves found in the Tranmer House cemetery, marking the grave out as distinctive. 


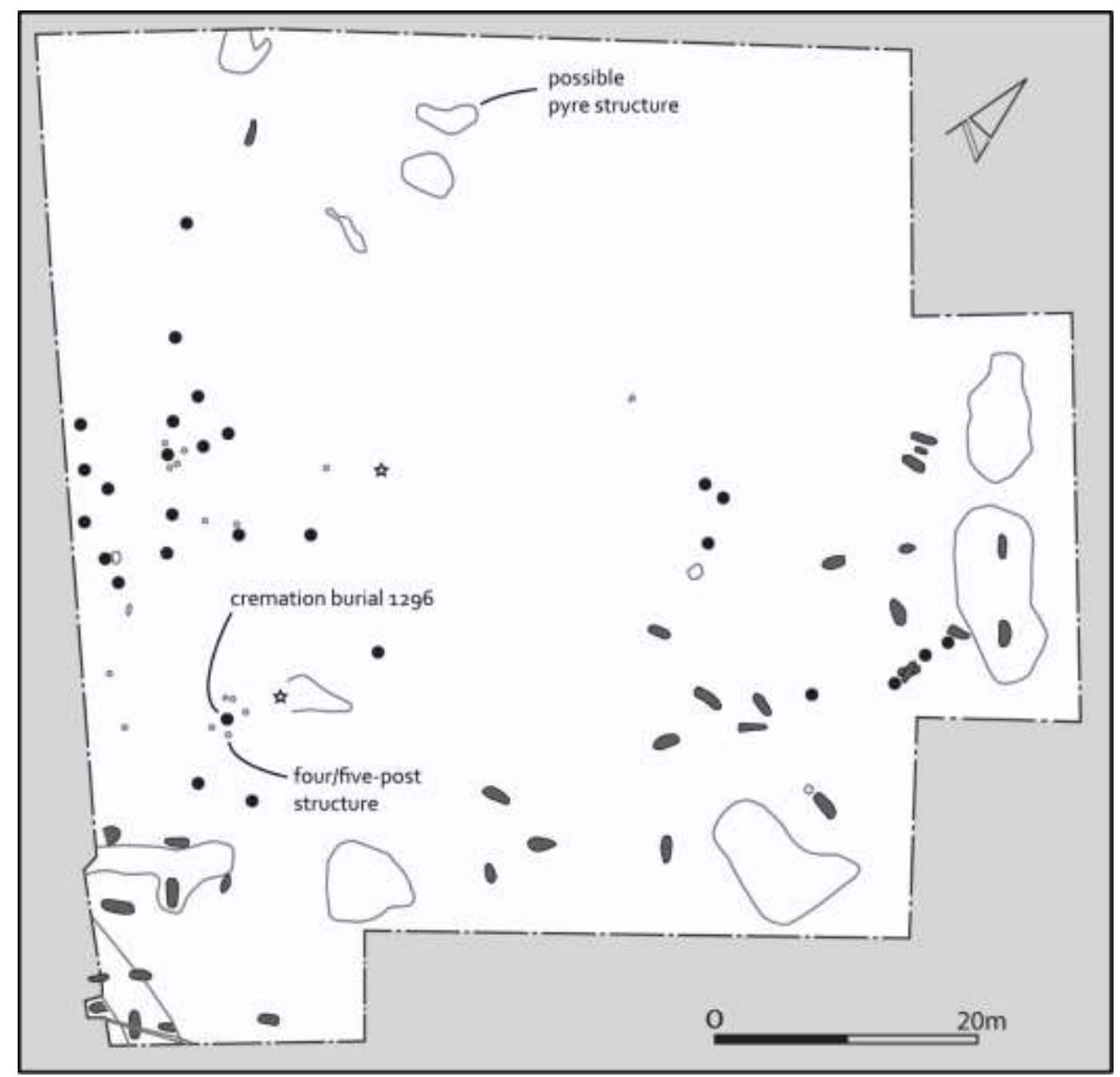

Illus. 7 Plan of the 'Minerva' Alwalton (Cambridgeshire). Redrawn after Gibson 2007 by Howard Williams

\section{Alwalton}

Another open-area excavation revealing an isolated mortuary structure is the Cambridgeshire cemetery of Alwalton (Illus. 7). The excavations found a cluster of four post-holes located around cremation 1296 . It was hypothesized by Gibson $(2007,242)$ that this may represent a post-built grave structure or canopy, or alternatively, made up a fence to segregate the burial. The possible funerary structure measures 2.3 by $1.67 \mathrm{~m}$. The burial itself contained an urned adult cremation, osteologically sexed as possibly a male.

The cinerary urn was interred with a fragment of antler comb which was a common artefact in many of the cremation burials from this site. However, it also contained rarer items: iron shears, razor and honestone (Gibson 2007, 244-45; 347). While comparable grave-goods are known elsewhere, and the majority of cremation burials at this site were associated with a comb, the iron shears, razor and honestone mark this grave as having potential significance. Spatially, cremation 1296 was located on the edge of the major cremation burial cluster found in the north-eastern section of the cemetery, and was also set apart from the mixed inhumation and cremation section in the south-east. Given both the location and grave-goods, it is highly likely that the post-holes found with the grave were another method of setting this individual apart in some fashion. Elsewhere, one of us has argued that toilet implements might sometimes serve to mark the graves of ritual 
specialists or elite individuals, with the toilet implements serving as instruments of their roles in caring for, and transforming cadavers (Williams 2015b). Therefore, as at the Tranmer House cemetery, a distinctive, if not high-status, burial identity was being communicated through its spatial position, the presence of a four-post structure, and the choice of urn and artefacts deposited in the grave.

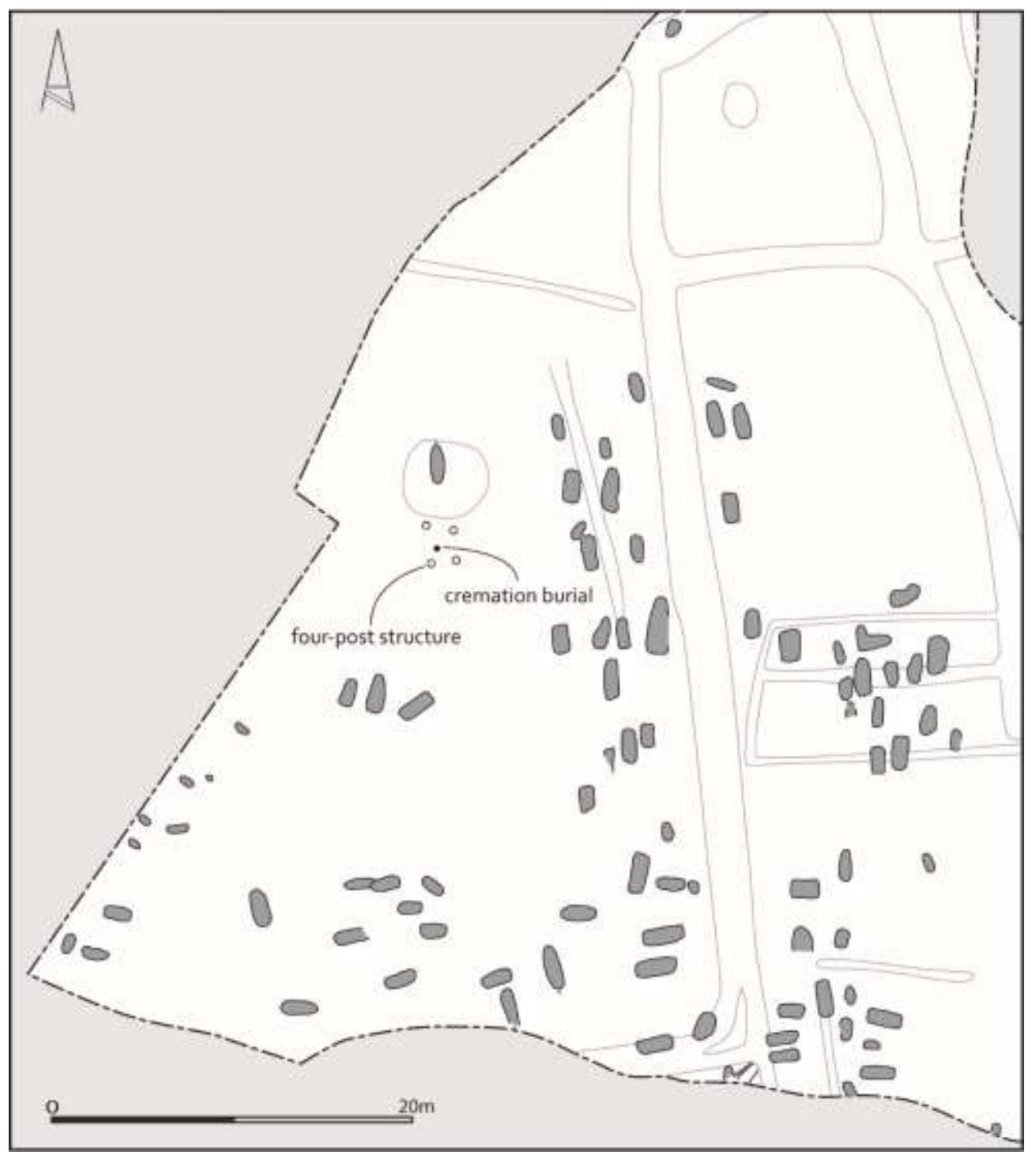

Illus. 8 Plan of the Wally Corner, Berinsfield cemetery. (Redrawn after Boyle et al. 1995 by Howard Williams)

\section{Berinsfield}

At Wally Corner, Berinsfield (Illus. 8) the excavated cemetery contained mainly inhumation graves, but three cremation burials were recovered (Boyle et al. 1995, 61-2). There were a distinctive pairing of burials to the north-west of the cemetery. Here, an early Bronze Age pond barrow received a centrally placed north-south aligned inhumation grave containing an elderly female with beads, a bone pin and a knife plus the disturbed foot bones of another individual (Boyle et al. 1995, 10-11, 123). Immediately to the south of the barrow and grave was a four-post structure surrounding cremation 111 . The structure measured 1.5 by $2 \mathrm{~m}$, and its post-holes varied in depths from 0.07 to $0.15 \mathrm{~m}$. The cremation burial was a single adult in a plain jar with two animal bones - an unburned sheep's rib and the calcined 
vertebra of a bird (Boyle et al. 1995, 11, 62). It is equally possible that these were chronologically disparate graves, or contemporaneous interments opting for contrasting burial traditions and for reasons unknown were placed away from other graves (Boyle et al. $1995,123)$. While the artefacts recovered are not particularly striking, what is notable is that again we have a cremation burial set apart from the other burial clusters and marked by a four-post structure as at Alwalton.

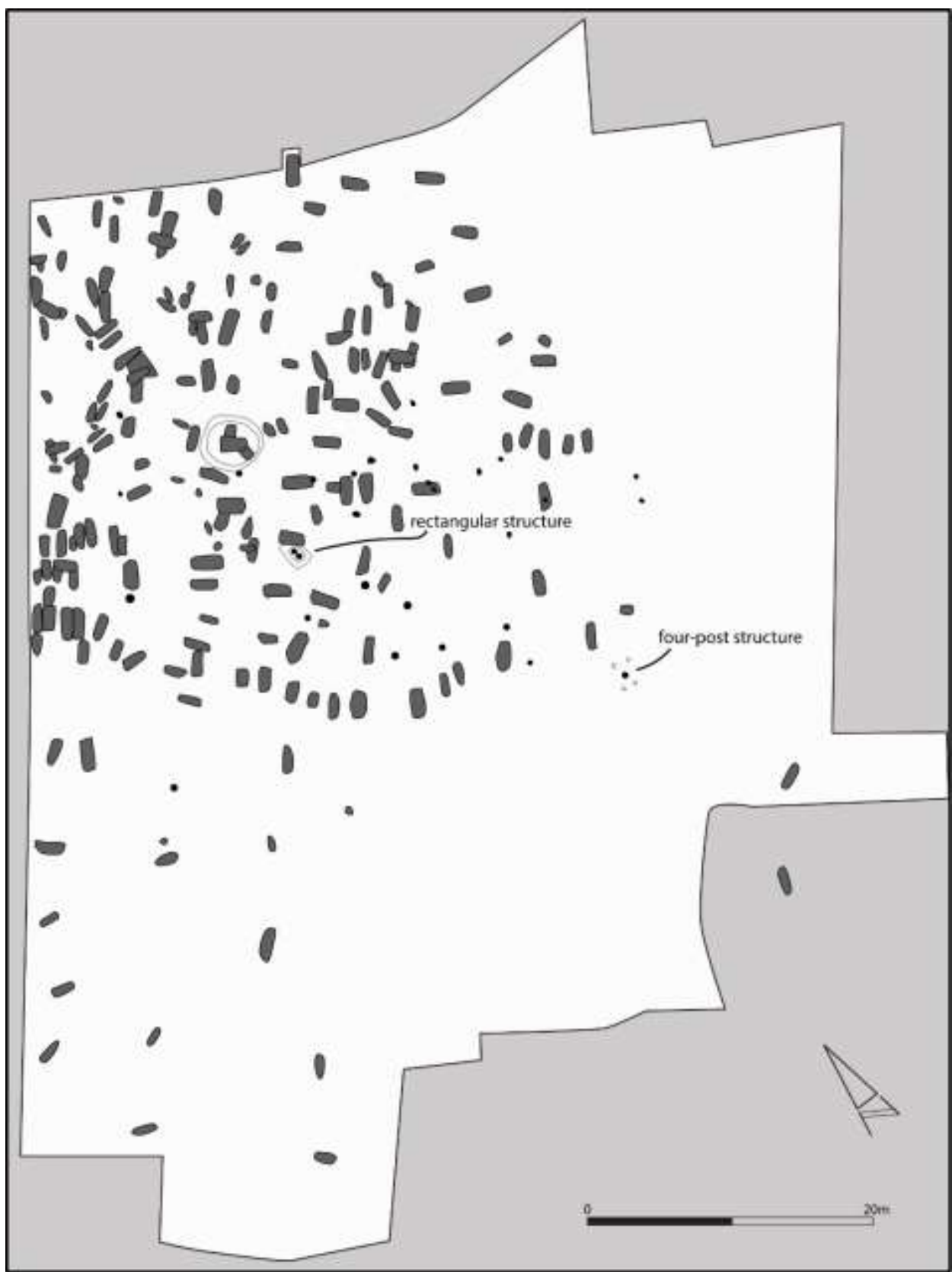

Illus. 9 Plan of the Lechlade cemetery. (Redrawn after Boyle et al. by Howard Williams)

Lechlade

At Butler's Field, Lechlade (Illus. 9), the long-lasting cemetery contained at least thirty cremation burials with further cremated bone found within inhumation grave fills. A rectangular gully was interred centrally within the cemetery and contained a pair of cremation burials. One cremation burial (226), an indeterminate adult with no associated finds, was found within a four-post structure on the very south-east edge of the cemetery 
(Boyle et al. 1998, 141; Boyle et al. 2011, 161). The post-holes measured 0.33-0.37 m in diameter and were 0.29-0.3 $\mathrm{m}$ deep. The structure was approximately 2.5 by $2 \mathrm{~m}$ large. Similar to Alwalton, the cremation within the structure was located at the edge of the major cluster of inhumation and cremation burials, and is set by itself in the southern portion of the cemetery. Due to ploughing and poor preservation at the site, only the base of the cremation survived and this may explain the lack of finds. Still, while a claim for 'high status' cannot be sustained on this evidence, spatial position and the presence of a structure seem to work together to mark out two sets of cremation burials in the cemetery.

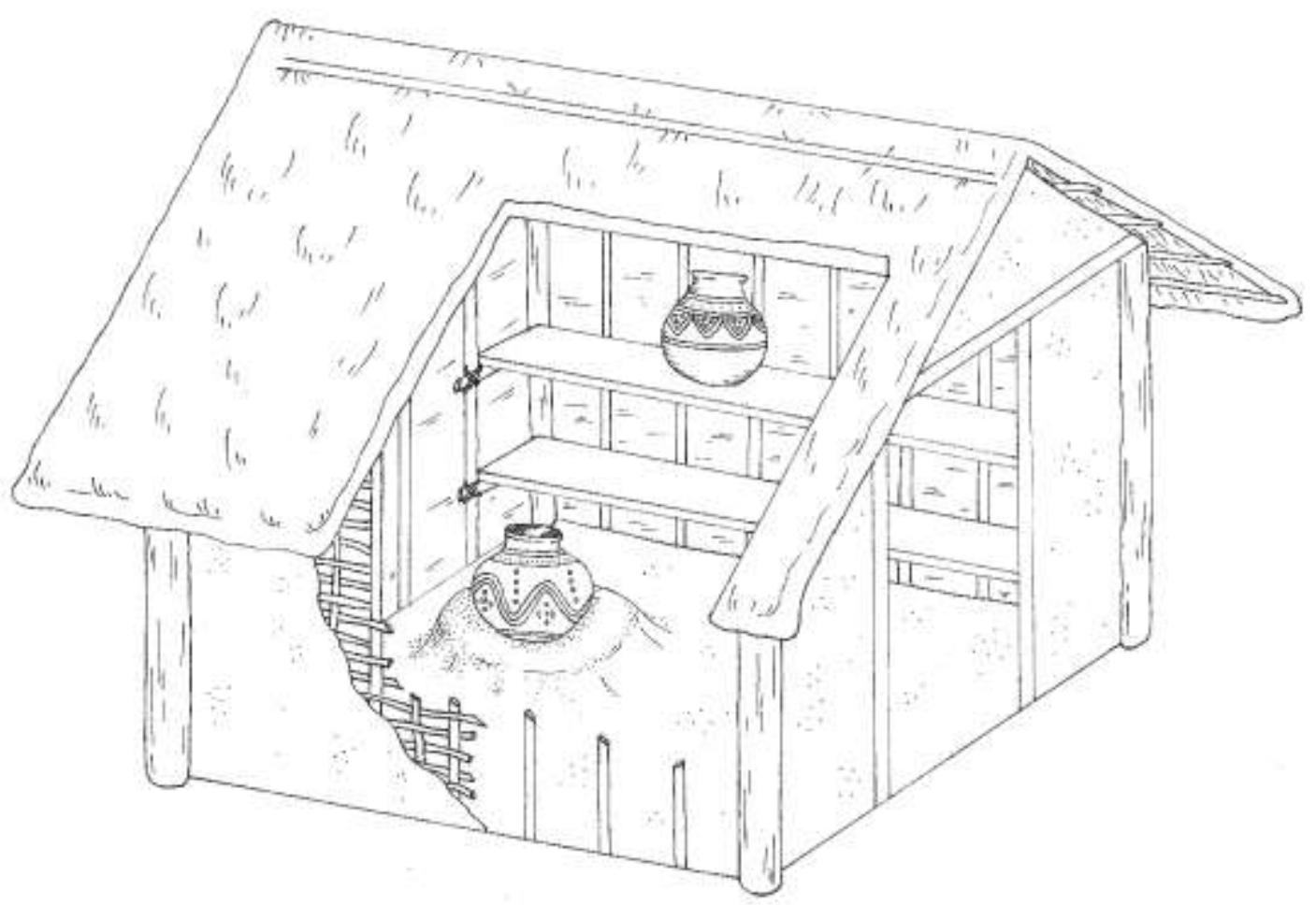

Illus. 10 Mortuary Structure illustrated by Meyers Emery, scale 2 inch = 1 metre, scale based on the Lechlade evidence

Discussion

With these examples, it seems to be the case that particular individuals or groups received access to these structures. There are a number of possibilities about what these isolated structures looked like (e.g. Illus. 10). Whatever the precise appearance, it is highly likely that the individual(s) buried within were afforded some type of special status. Given the visibility of these within the cemetery, for months and years, if not decades, the structure may have aided in promoting specific memories of the deceased and reinforcing the relationship between the dead and mourners. 
We need to consider further the potential significance of mortuary structures in the cremation process itself. First, these structures may have, in part, served in the precremation laying out of cadavers for cremation or inhumation burial, as argued for SFBs at the Mucking II and Street House cemeteries (see above, Hamerow 2012, 121). At Apple Down, there are a number of structures that have no specific burial present within them, and the associations with both inhumation graves and cremation burials may support this argument. Further, the spatial separation of the singular structures may suggest that they were meant to be kept apart while the corpse was undergoing the first stages of transformation. We concede that such practices will leave no archaeological trace, and in any case, are not mutually exclusive to these being places for the interment or storage of ashes (see below).

Following cremation, mortuary houses may have also acted as canopied open-air spaces for the sorting of ashes before burial and adding grave-goods to the funerary urn or other cinerary container. From what is known of early Anglo-Saxon burial practices, these structures may have played a role in 'rebuilding' the body prior to burial, with the burial inside the structure acting as a protective ancestor during this liminal period of transformation. Hence, these may have been places where the cremains were stored while pyre-goods were sorted and grave-goods were added, before or during the excavation of a grave. As Williams $(2007,2014)$ has previously argued, the artefacts, specifically the presence of toilet implements and combs, and use of burial urns in this period, may suggest that the dead go through a process of regeneration and fermentation following the cremation: body-building. It is possible then that these structures protected the deceased during this transformation, and following this liminal period, mourners could bury the dead in its new form as an ancestor. Setting the structure apart would have maintained distance between the newly dead and ancestors (those whose graves already inhabiting the cemetery) during this liminal period.

For example, at Alwalton, the only straight line of burials extends northwards from the possible four-post 'mortuary house', and may suggest that this location was used for display prior to burial. It is also feasible that at Apple Down, different families or households used their own mortuary structures for the preparation and protection of the dead between burning and burial. The lack of graves within some of the mortuary structures may support this conclusion, with perhaps a younger household lacking the original burial and using the structure for staging and preparation alone. A final, and not necessarily contradictory notion is that mortuary houses afforded the possibility of roof-spaces, shelves and raised floors in which many dozens of bags (of leather or textile perhaps) and/or ceramic urns containing ashes could be stored and/or displayed for years after their disposal at the cemetery (Illus. 10). As mentioned above, cremation 45 at Alton was perhaps a structure which may have contained aboveground, ground-surface or very shallow cremation deposits (Evison 1988, 88). Conclusive proof of this will be difficult to ascertain but it is proposed that these timber mortuary structures may have been intended as miniature columbaria.

As well as evidence that mortuary houses might attract clusters of both cremation and inhumation graves discussed below, at Lechlade there was a pairing of cremation burials 
(222 and 224) within a rectangular gully (Feature 12) cut by a later west-east aligned seventh-century inhumation grave (Boyle et al. 1998, 140-41; Boyle et al. 2011, 160). While plausibly contemporaneous deposits, it does hint that these structures could be related to multiple (and perhaps successive) burial events, with centrally placed cremation pit 224 and joined slightly later and off-centre grave 222 (Boyle et al. 2011).

At Collingbourne Ducis (Illus. 11), two rectangular structures were identified. One was made of four post-holes and connecting gullies/beam slots measuring c. $1.75 \mathrm{~m} \times 1.5 \mathrm{~m}$. The other comprised of four post-holes creating a structure measuring c. $2 \mathrm{~m} \times 1.5 \mathrm{~m}$. This could be a possible indication of the graves of individuals of 'higher than average standing in their community' (Stoodley 2015, 146). The large-scale excavationsonly found a third, penannular ditch, and it is unlikely that large numbers of these features would have been missed. While cremated material was found in the gullies and post-holes, none were discernibly primary deposits from pyres or can be convincingly regarded as constituting a cremation burial (McKinley 2015, 98-99).

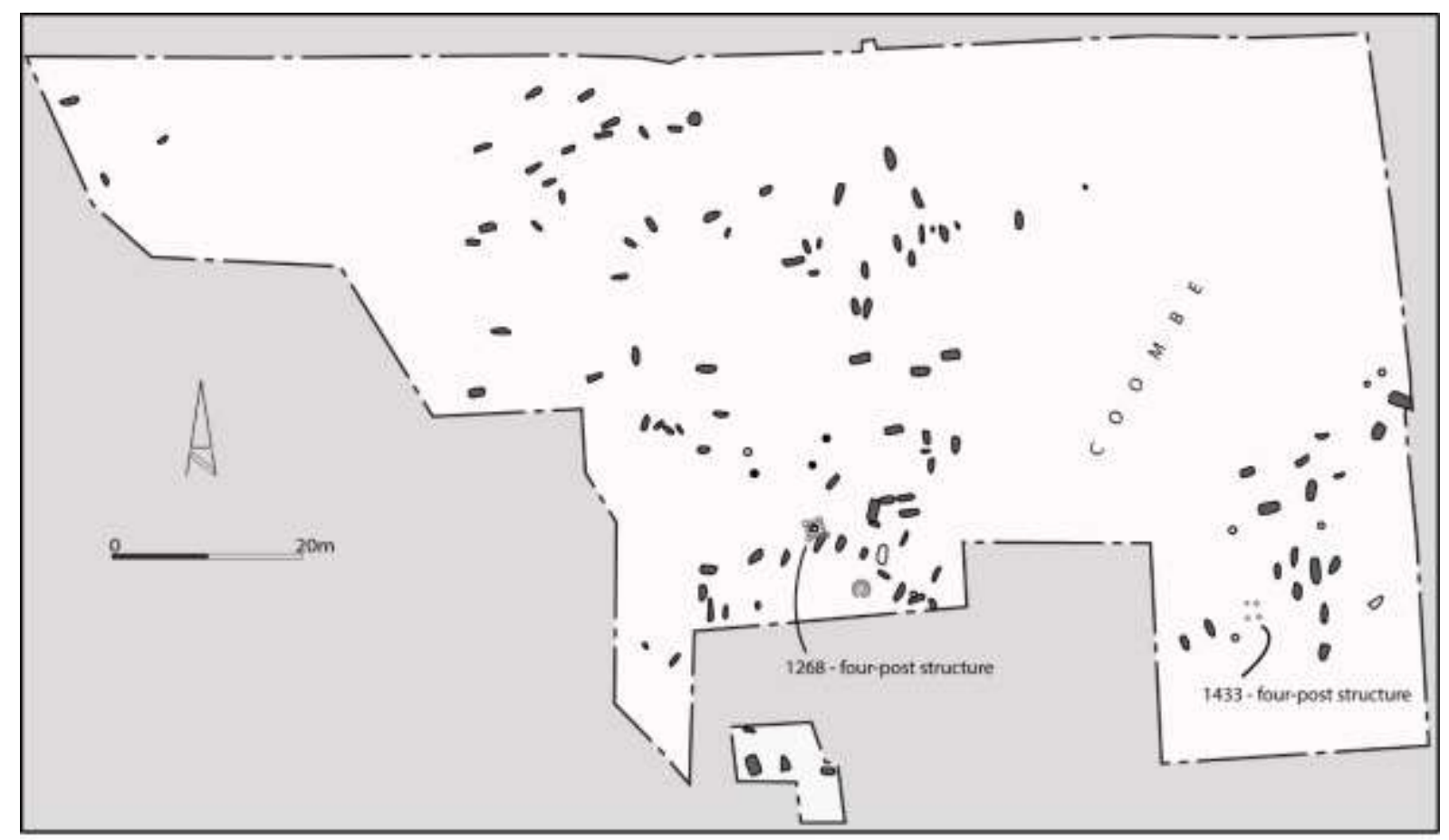

Illus. 11 Plan of the Collingbourne Ducis (Wiltshire) cemetery showing the four-post structures on either side of the combe. (Redrawn after Egging Dinwiddy and Stoodley 2005 by Howard Williams)

This takes us back to Apple Down where there were multiple mortuary houses which can be questioned as monuments raised over cremation 'graves' at all, given the lowbone-weights of the deposits (see also McKinley 2003, 18). At Apple Down, the mortuary houses without cremation burials are plausibly explained by Down and Welch $(1990,29)$ as evidence that central cremations were covered by low mounds and thus were buried on the surface or within the subsoil without creating a grave cut into the chalk. Yet a further scenario is that, within these structures, the central cremation deposits were suspended, raised up on plinths or mounds and were thus never 'buried' at all. Down and Welch $(1990,29)$ explain cremation deposits in post-holes ofmortuary houses as either 'foundation deposits' perhaps from the same funerary episode or secondary cremation burials added during repairs to the 
structures, implying a longer duration of these structure's use and reuse. However, McKinley $(2003,18 ; 2015,99)$ rightly queries whether any deposits of cremated bone associated with these mortuary structures can legitimately be regarded as 'cremation graves', given their low bone weights. Instead, it might be argued, as with the Croydon postulated four-post structure, and CollingbourneDucis structure 1268, that these are redeposited cremated materials. While one might suggest they came direct from a justcooled pyre, a viable explanation is that these were remains initially storied on the ground, or above-ground, within the square and rectangular structures. In short, a strong possibility is that these structures might be primarily columbaria rather than grave monuments.

\section{CEMETERY FOCI}

In contrast to the singular structures, the cemeteries at Lechlade, Collingbourne Ducis, Alton (Illus. 2) and Apple Down (Illus. 3) revealed multiple structures built during the cemetery's duration of use. The presence of more than one structure indicates these buildings may have had a different purpose or meaning behind them that needs to be explored further.

The site of Apple Down has thirty-three mortuary structures, thirty-one of which are associated with traces of cremation. Little information is available about the cremains found within these structures, however those identified included both adults and subadults. No grave-goods were identified and only one cremation was found in an urn. The structures found range in size from the smallest at one metre square to the largest at 2.7 by $2.5 \mathrm{~m}$ (Down and Welch 1990). The mortuary houses at Apple Down were fully interspersed throughout the cemetery with cremation and inhumation graves, making it difficult to discern any chronological and spatial patterns. However, on the southern and eastern quadrants of the cemetery there were few inhumation graves and a predominance of mortuary houses, suggesting a clear zonation - whether chronological or contemporaneous. What is notable is that this was not zonation between cremation and inhumation per se but between mortuary houses and other graves.

At Alton (Illus. 2), the two mortuary structures were discrete from each other, but might be argued to have been foci within burial clusters comprising of both inhumation and cremation graves. The evidence found around cremation burial 7 indicated the presence of a four post-structure, and a number of artefacts were found, including an iron nail, bucket binding, iron pin, beads, a number of bronze, iron and silver fragments. Within the fill of the structure was a range of calcined bone, which could not be identified as either human or non-human. Cremation 5 was a truncated shallow burial just outside of the rectangular gully focusing on cremation 7 . The structure itself was at the focus of a cluster of pits containing cremation burials $(6,13,14,15,17,22,23$ and 24) and at least one inhumation grave: an older adult with female-gendered grave-good sincluding a pair of saucer brooches but osteologically sexed as male (Evison 1988, 74). 


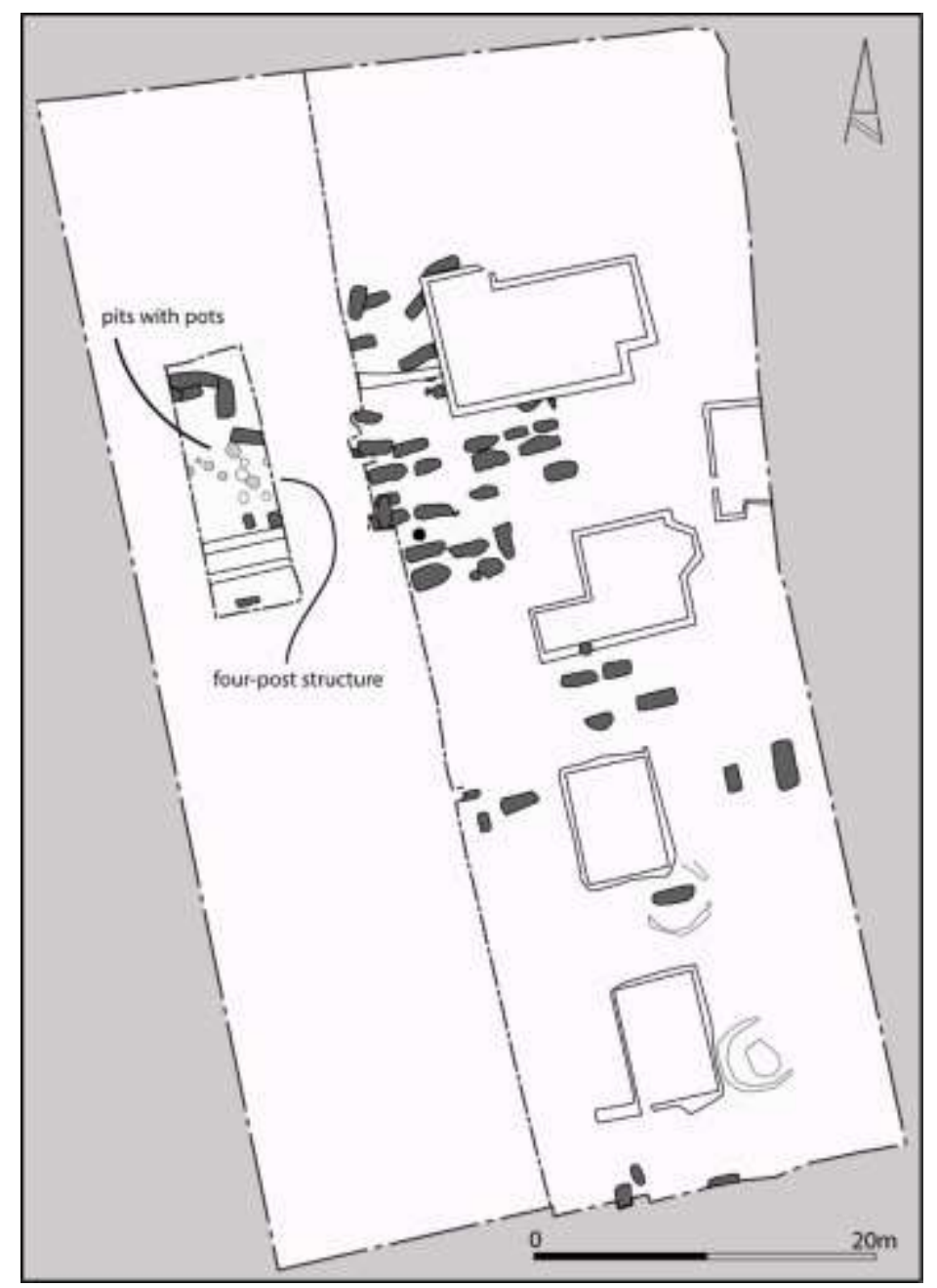

Illus. 12 Plan of the Croydon cemetery with a possible four-post structure associated with pits contained buried pots without cremated remains. (Redrawn after McKinley 2003 by Howard Williams)

Cremation 45 at Alton was a rectangular flat-bottomed gulley cut through an earlier cremation (33) and itself contained no cremated material. Unlike the structure found around cremation 7, this one consists of smaller stake-holes that may have been used to create a platform rather than a structure. It is either not actually a cremation burial, or else the deposit(s) of cremains were too shallow to survive or else above ground (Evison $1988,88 ; 117)$. Meanwhile, cremation 32 was to its east (Evison 1988, 87), cut in half by the digging of two end-to-end later inhumation graves containing an adult female with a pair of saucer brooches beads and other dress accessories (23) and an adolescent with a knife and buckle $(24)$ (Evison 1988, 77). The cutting of the earlier cremation grave might appear to be disrespectful or incidental, were it not for the fact that the alignment of the two inhumation graves coincides almost exactly to that of the rectangular post-and-trench structure surrounding cremation 7 (Evison 1988, 37).

The partially excavated example from Park Lane, Croydon (Greater London, formerly Surrey) (Illus. 12) is intriguing in this regard, since while only one cremation burial was investigated, a series of excavated pits containing pots were also found in association with a possible four-post structure. One of these was investigated and found to be a buried pot without cremated remains. McKinley (2003) proposes these are 'cenotaph' or 'memorial' 
deposits, perhaps to those who were interred elsewhere, honouring those who died during the early phases of the 'Anglo-Saxon migration' into the region. An alternative possibility is that mortuary practice involved a four-post building built around a deposited vessel (76) while the ashes were distributed elsewhere or above-ground in the building itself, as argued above (McKinley 2003).

The archaeological evidence, including the widespread use of mortuary houses at Apple Down, leads to an intriguing possibility that perhaps the use of these structures represent a distinctive mortuary strategy from inhumation burial and cremation burial. Lechlade, Collingbourne Ducis's and Alton's two structures may represent something in between Apple Down and the isolated structures found elsewhere. Likewise, the Spong Hill PG5 structures, adjacent to, but separate from, cremation burials, might constitute aboveground repositories for a multitude of cremated remains and simultaneously foci for cremation burial to their east. The amassed evidence questions our below-ground focus and the 'bi-ritual' characterization of interpretations of early Anglo-Saxon cemeteries.

\section{ETHNOGRAPHIC EVIDENCE FOR MORTUARY HOUSES IN CREMATION PRACTICES}

Many archaeologists have repeatedly exhibited caution at the use of ethnographies to inform their interpretations of mortuary practice, famously exhibited in Peter Ucko's provision of ethnographic cautionary tales to problematize archaeological interpretations (Ucko 1969). Early Anglo-Saxon archaeologists have taken these cautions to heart and hardly ever explore ethnographic evidence (for a fuller review, see Williams 2016). While no one-to-one parallel of form and significance is intended, the ethnographic record for cremating societies from across the world has been systematically explored by the authors. Accounts rarely give us all the necessary information, yet this data does reveal facinating instances of mortuary architectures for the cremated dead that might assist in our archaeological interpretations (see also Downes 1999; Williams 2016). (Note, while many of the practices discussed relate to living traditions, the age of some of the ethnographic sources makes it appropriate to refer to these examples in the past tense.)

Ethnographies for cremating societies were gathered from a wide range of sources by during doctoral research by Williams (2000). While no claim is made that they are xhaustive, the global survey reveals a range of contrasting socioeconomic, cultural and religious environments in which architectures can operate in cremation ceremonies. This extensive evidence shows a surprising range of ways in which pyre architectures were deployed involving posts to frame them and in ways that would leave little archaeological trace, but also the wide range of fashions by which miniature houses and structures could be built as temporary and semi-permanent repositories for the cremated dead once ashes have been retrieved from the pyre, curated and contained above ground. Buildings can be raised over cremation burials but also the pyre-site itself. This survey of the ethnographic literature suggests three common themes for the use of mortuary 'houses': 1) a temporary housing place for the soul before it departs, 2) a method of protecting the newly deceased while they are in a liminal state, and 3) marking the distinctive identity of a deceased individual or individuals. These do not map onto the early Anglo-Saxon mortuary data directly. Indeed, given the nature of ethnographies, rarely do these accounts address relationships between funerals or indeed specific details of cemetery spaces. Although 
these ethnographic accounts do not address all the material and spatio-temporal dimensions and issues, they facilitate our interpretation of the early Anglo-Saxon cemetery data.

\section{TEMPORARY HOUSING}

Ethnographies from Nivkh groups in Siberia reveal the use of mortuary houses as temporary repositories for the dead following cremation; the pyre-site becomes elaborated with a memorial shrine in the form of a small house containing a stylized wooden image cut and dressed in miniature garments and equipped with all the paraphernalia of the living person including a knife, needle case, tinder and flint (Czaplicka 1914, 151-52; Black 1973). These houses are believed to offer the soul with a place to reside while they are temporarily confined to earth (Zgusta 2015, 302). In this instance, the cremation pyre became the site of elaboration and the aim was to use the cremated remains and other objects to create a temporary dwelling place for the deceased soul. The memorials were not enduring, but their intention is quite different: to present a place of mediation with the supernatural world and enable the journey of the dead towards it.

A similar situation took place among the Athabascans of Alaska who practised the tradition of building 'spirit houses' for the dead. These structures provided a place for the deceased's soul to dwell over the course of forty days, when it is believed that the spirit must remain on earth. Traditionally, the body was cremated and then stones and blankets were placed on top of the pyre, and then a wooden built miniature house is placed over the top. Today, the spirit house tradition remains, although blending with Russian Orthodox beliefs has led to a switch to inhumation and the addition of crosses to the houses (Flintoff 2012).

Therefore, one possible hypothesis for early Anglo-Saxon England is that the mortuary houses were not intended as long-lasting grave-markers, but as relatively ephemeral repositories for the dead to reside after cremation as part of a conception of the soul or spirit as requiring a home following the body's conflagration and the collection of the ashes. While the evidence outlined above counters such a short duration to some of the structures, the association of these structures, less as repositories but more as temporary dwellings for the spirits of the dead, needs careful consideration.

\section{PROTECTION FOR THE NEWLY DECEASED OR THE LIVING}

These mortuary structures can also be perceived as protecting the dead or the living during the liminal period between death and becoming part of the spirit world. There are instances found among the Kacharis of Assam where simple four-post structures enclose the site of cremation itself (Endle 1911, 48) mirroring the treatment of inhumation graves in the same communities: threads of cloth were passed around four posts erected around the grave in order to prevent the spirits of other men from interfering with the repose of the newly deceased. Similarly, the Garos of Bengal (Meghalaya and Bangladesh) buried ashes in the earth at the same spot as the pyre was kindled. Subsequently, a small thatched building was built, surrounded by a railing, and serving to record the memory of the deceased and assuage the ghost from returning to haunt the living (Crooke 1896, 288; Downe and Fraser 1939, 259). In these instances, asserting distance and protection between the living and the dead can be conceptualized as a commemorative strategy by ensuring the dead do not 
attempt to return to haunt or pollute the living. In other words, this is a technology to ensure the transformation of the dead into an ancestor.

Likewise, in Burman cremations, a miniature pagoda might have been erected over the ashes of highly respected relatives as a way to both pacify the deceased and protect the living (Yoe 1896, 590). For similar reasons, among the Lao Song of northern Thailand, the cinerary jar was buried and a straw-thatched house on a post was erected as a replica of an ordinary dwelling house of the deceased (Rishøj Pedersen 1974/5, 356). In these instances, the miniaturization of dwelling houses and their temporary nature does not detract from their key importance in staging communication and commemoration in the days, weeks or months following the burning of the deceased. These examples seem to perpetuate the theme of temporary residence for the cremated dead within diminutive dwellings.

\section{SOCIAL IDENTITIES IN DEATH}

There are instances where mortuary houses might be utilized to mark out those special or distinctive identities in death. Among the Tlingit (Kan 1989), mortuary houses were set apart from other graves and contain the remains of shamans. In Tibet where cremation was reserved for high lamas, the ashes were scraped together and mixed with clay and moulded into tiny pagodas, and thus distributed through the landscape (Habensten and Lamers $1963,81)$. In Laos, the remains were collected and placed in a pagoda until a permanent monument was erected for a high-status person (Habenstein and Lamers 1963).

Throughout regions influenced by Buddhist traditions, stupas - mound-like house tructures - can be built to hold the remains of monks and nuns. The form of the stupa could vary depending on the region in which it is located, and often represents the style of housing seen in that area. These locations might be revisited by the living to seek guidance and meditate in the presence of the holy dead (Fogelin 2013, 236; Ebrey 1990). Not only can these locations be perceived as residences for the dead, they also become place for commemoration and focal points for devotional activity.

Whether constructed over pyre-sites or graves, these miniature structures might embody sophisticated social and cosmological associations, serving to facilitate the transformation of the dead - singly or collectively - into ancestral presences in the landscape and/or into the next world. While ethnographies do not pin down any single interpretation for the early Anglo-Saxon cemeteries in which cremation is found, these arguments serve to highlight the value of thinking through ethnographic evidence to provide insights into the appearance and significance of modest architectures to house the cremated dead. In particular, these sources reveal the potential of miniature structures to be invested with social and cosmological significance in the transformation and commemoration of the cremated dead, involving both ideas of temporary dwelling and protection and sometimes utilized to mark out the social or religious identities of those associated with them. 


\section{DISCUSSION}

John Blair (1995) discussed square timber structures as possible pagan shrines (see also Semple 2011). These structures may well have had significance beyond mortuary processes, but it is the relationship with the process of burning and disposing of cremated material that is key to the interpretation of most of the structures reviewed in this study. Recently, archaeologists have begun to critique the perceived division between settlement and cemetery space, with Hamerow (2012) reviewing 'placed' deposits in settlement contexts associated with halls and Soffield (2015) suggesting that these deposits were connected to the life-histories of buildings, and perhaps that buildings were regarded as living entities requiring funerary deposition. Burning halls and burning bodies were certainly features of the early Anglo-Saxon world, and whether they were connected together in funerary ritual remains to be fully explored. What the evidence here shows is how cremation and timber structures might be connected together at one or more stages of early Anglo-Saxon funerals. While the ethnographic evidence does not map directly onto the archaeological data, there is support for the argument that these mortuary structures may represent postcremation cemetery architectures, perhaps employed as repositories for particular individuals or groups above rather than primarily below ground. As such, they were perhaps used to protect the dead in their afterlife journey and/or serve as commemorative loci for mourners. As a result, they might constitute semi-permanent dimensions of cemetery topography, stages for ritual actions involving the placing of cremains, the commemoration of the dead, and thus both respected and attracting a succession of cremation burials and inhumation graves.

The implications of this argument are more startling than might first seem apparent. In the light of this discussion, archaeologists suddenly find themselves having to revaluate their perception of early Anglo-Saxon England mortuary processes as involving a choice between two principal disposal methods for the dead: cremation burial and inhumation burial. Instead, a new characterization of the mortuary trajectories used by the rural communities found across southern and eastern England in the fifth and sixth centuries can be proposed. Rather than possessing a 'bi-ritual' mortuary programme - with cremation and inhumation deployed in different ratios - as proposed by Williams (2002), we might entertain the existence of a 'tri-ritual' mortuary programme:(i) inhumation burial, (ii) cremation burial in pits and graves, and (iii) cremation followed by storage above, upon and below ground within mortuary houses. These disposal options were deployed together in varying proportions within and between cemeteries.

Based on this supposition, there are a number of possible relationships between the burials associated with mortuary structures and those not.

1. Separate mortuary programs: as argued above, the presence of mortuary houses may indicate that mourning communities had three choices for the funeral including inhumation and burial, cremation and burial, or cremation and use of the mortuary house for display, preparation or other purposes. Given that mortuary structures are primarily found in mixed-rite (bi-ritual) cemeteries with cremation and inhumation, these were places where diversity in practice was already allowed, so expansion to a third program may not be a stretch;

2. Same mortuary programs, but different stages: we can also propose that the use of mortuary structures may have been part of the bi-ritual funerary process. Given the 
breakdown of the body during cremation, the dead may have required an extra step to allow them to become full 'ancestors' or reach the desired afterlife destination. These houses may have served as places to protect the dead and/or the living during a liminal period leading up to burial elsewhere, or perhaps as a stage after cremation burial, when ashes were exhumed and interred above ground.

3. Same mortuary program, but for special individuals or groups: finally, the structures may have been used to mark individuals of a distinctive social identity or status. If status or identity was marked by the duration as much as investment in the funeral, maybe a high-status individual or household may have marked their importance by having the sensory and elaborate experience of the pyre, and then continued to show their status through the erection of a more permanent structure.

Alternatively, the use of the structure may have been a way of marking deviant individuals who were buried in the mortuary houses to protect the living and/or the rest of the burial population.

Beyond their building, use, possible repair and decay within and between mortuary practices, it is also important to consider how these timber 'mortuary houses' contribute to cemetery topography. Once constructed for whatever reason, these timber structures would have become a highly visible part of the cemetery's landscape. Cremation afforded the opportunity to bury or house the dead in shallow graves in close proximity to each other. Indeed, in many larger cremation cemeteries like Spong Hill, cremation burials appear to have shared burial pits, or were placed in lines and curves, suggesting close spacing within communal monuments or the augmentation of existing mounds with each new burial. Despite the lack of surviving structures and monuments at most sites, this proximity in itself was a form of cumulative architecture that made cremation cemeteries a distinctive space and a striking place where success interments forged affinities between the living and the dead. Individually modest and ephemeral, architectures afforded a process of commemorative citation in which modest above-ground memorials sufficed to cite links with earlier graves and gradually become conflated with them, enchaining successive funerary episodes to the place of deposition.

The relative ephemerality of these structures should not be over-estimated. The short tempo of construction and survival may have been a deliberate and key aspect of the commemorative practices that focused on the material forgetting of the dead. However, the accumulation of successive structures affirmed and perpetuated the burial site as a place of memory where ancestors (individually or collectively) were commemorated both through cumulative architectures as much as individual memorials.

A further point might be raised. Elsewhere, it has been argued that large burial mounds with rich assemblages of the late sixth and seventh centuries AD aimed to impress the personalities of the dead and their kin onto the landscape, through the creation of 'dwelling', and perhaps even 'watching', presences of ancestors (Williams 2011bb; see also Nugent and Williams 2012). Given the attention given in recent years to the ritualized dimensions of early Anglo-Saxon settlement spaces (Hamerow 2012; Soffield 2015), we can develop this argument further, and pitch it earlier, when considering the significance of providing timber 'mortuary houses' for the early Anglo-Saxon cremated dead. In this sense, cemeteries might be regarded as collective 'homes' for the early Anglo-Saxon dead, 
perhaps constituting a repository for families or households, their life histories charting the ebb and flow of the social groups using them (cf. Eriksen 2015; Gardeła 2016).

\section{CONCLUSION}

This article has not attempted to explore Continental and Scandinavia parallels, although Fern (2015) rightly draws attention to the various interpretations of similar structures as pyres or mortuary houses beyond early Anglo-Saxon England (e.g. Høilund Nielsen 2009; Annaert et al. 2011). Not only do we recommend that future work investigates more careful comparisons and contrasts with this evidence than has hitherto been conceived, but that there is considerable scope for the careful evaluation of site archives to elucidate further details about these features, even when revealed by careful modern excavation methods. Certainly, future excavations of early Anglo-Saxon cemeteries need to prioritise careful and systematic investigations of these structures, and their connections to ephemeral traces of deposits of cremated human remains associated with them. In doing so, we can further elucidate posts and gullies which might relate to multiple stages in the cremation of the dead. For the English evidence published to date, the article presents the first cohesive interpretation as to their significance, drawing on ethnographic analogies and mortuary theory. While the archaeological evidence remains tentative and confined to only certain cemeteries, and although no single ethnographic analogy explains the varied use of these structures in different early Anglo-Saxon burial sites, we suggest that more refined and developed interpretations of these structures enrich our appreciation of early Anglo-Saxon mortuary practice's spatial, material and architectural dimensions. In particular, the evidence might indicate our widespread side-lining of structures deployed for housing and commemorating of the early Anglo-Saxon cremated dead prior to the deployment of large cremation burial mounds appear in the late sixth/early seventh centuries AD.

Early Anglo-Saxon cemeteries of the fifth and sixth centuries AD might have been marked in many ways; the concept of 'flat cemeteries' (as opposed to 'barrow cemeteries') needs to be now robustly discarded. In particular, we have presented the case that certain timber mortuary structures were an important dimension of some cemetery topographies. They may have held multiple levels of significance for the communities deploying them. While more information is clearly required to ascertain their frequency in cemeteries, relationships with other burial structures and monuments, their duration, use and repair, they could have operated as locations for either specific and generalized commemorative behaviours by early Anglo-Saxon period communities. Arguing against their function as pyre structures or mortuary monuments raised over single cremation graves, we suggest they would have been highly visible enduring features within the landscape of particular cemeteries, perhaps aiding in the production and transformation of memories and identities through and between different funerary episodes. As possible 'columbaria' or temporary stages for storing the cremated dead in a collective fashion, they have been architectures that facilitated a perception of the cremated dead as dwelling together as a miniaturized community within the burial ground. As such, these features are an important key to further understanding the distinctive nature of cremation practice in early AngloSaxon England (see also Williams 2014). Moreover, the article proposes the perception of, and prominence of, some cremated individuals and groups as dwelling and enduring aboveground within structures within some early Anglo-Saxon cemeteries. 


\section{BIBLIOGRAPHY}

Annaert, R., Deforce, K. AND Vandenbruaene, M. 2011. The cremation graves at the Broechem cemetery (prov. of Antwerp, Belgium), in T. A. S. M. Panhuysen (ed.)

Transformations in North-Western Europe (AD 300-1000), Neue Studien zur

Sachsenforchung Band 3, 207-17, Hannover: Niedersäachsiches Landesmuseum

Black, L. 1973. The Nivkh (Gilyak) of Sakhalin and the Lower Amur, Arctic Anthropol., 10, 1110

Blair, J. 1995. Anglo-Saxon pagan shrines and their prototypes, Anglo-Saxon Stud. Archaeol. and Hist., $8,1-28$

Bond J. 1996. Burnt offerings: animal bone in Anglo-Saxon cremations, World Archaeol., 28(1), 76-88

Boyle, A. 2011. Grave structures, in Boyle et al., 158-60

Boyle, A., Dodd, A., Miles, D. and Mudd, A. 1995. Two Oxfordshire Anglo-Saxon Cemeteries: Berinsfield and Didcot, Thames Valley Landscapes Monogr. No. 8, Oxford: Oxford Archaeological Unit

Boyle, A., Jennings, D., Miles, D. and Palmer, S., 1998. The Anglo-Saxon Cemetery at Butler's Field, Lechlade, Gloucestershire, Thames Valley Landscapes Monogr. No. 10, Oxford: Oxford Archaeological Unit

Boyle, A. Jennings, D., Miles, D. and Palmer, S. 2011. The Anglo-Saxon Cemetery at Butler's Field, Lechlade, Gloucestershire, Thames Valley Landscapes Monogr. No. 33, Oxford: Oxford Archaeological Unit

Carver, M. 2005. A Seventh-Century Princely Burial Ground and its Context, Rep. Res. Comm. Soc. Antiq. London, No. 69, London: The Society of Antiquaries of London

Cook, A. and Dacre, M., 1985. Excavations at Portway, Andover 1973-5, Oxford University Committee for Archaeology Monograph No. 4., Oxford: Oxford University Committee for Archaeology

Crooke, W. 1896. Primitive rites of disposal of the dead, with special reference to India, $J$ Anthrop. Inst. Great Britain and Ir., XXIX (New Series Volume II), 271-94

Czaplicka, M. A. 1914. Aboriginal Siberia: A Study in Social Anthropology, Oxford: Clarendon

Dickinson, T. and Speake, G. 1992. The seventh-century cremation burial at Asthall Barrow, Oxfordshire, in M. Carver (ed.), The Age of Sutton Hoo, 95-130, Woodbridge: Boydell

Down, A. and Welch, M., 1990. Chichester Excavations VII, Chichester: Chichester District Council 
Downe, R. A. and Fraser, J. G. 1939. The Native Races of Asia and Europe, London: Pery Lund Humphries Ltd

Downes, J. 1999. Cremation: a spectacle and a journey, in J. Downes and T. Pollard (eds) The Loved Body's Corruption: Archaeological Contributions to the Study of Human Mortality, 19-29, Glasgow: Cruithne

Ebrey, P. 1990. Cremation in Sung China, Amer. J. Hist., 95, 406-28.

Egging Dinwiddy, K. and Stoodley, N. 2015. An Anglo-Saxon Cemetery at Collingbourne Ducis, Wiltshire, Wessex Archaeol. Rep., 37, Salisbury: Wessex Archaeology

Endle, S. 1911. The Kacharis, London: MacMillan

Eriksen, M. H. 2013. Doors to the dead: the power of doorways and thresholds in Viking Age Scandinavia, Archaeol. Dialogues, 20, 187-214

Eriksen, M. H. 2016. Commemorating dwelling: the death and burial of houses in Iron and Viking Age Scandinavia, European J. Archaeol., 19(3), 477-96

Evison, V. I. 1988. An Anglo-Saxon Cemetery at Alton, Hampshire, Hampshire Field Club and Archaeological Society Monogr., 4, Stroud: Sutton

Fern, C. 2015. Before Sutton Hoo: the Prehistoric Remains and Early Anglo-Saxon Cemetery at Tranmer House, Bromeswell, Suffolk. East Anglian Archaeol., 155, Ipswich: Suffolk County Council

Flintoff, C. 2012. In Alaskan cemetery, Native and Orthodox rites mix. On National Public Radio. Electronic Document. http://www.npr.org/2012/06/25/155431017/in-alaskancemetery-native-andorthodox- rites-mix, Accessed 4 September 2015

Fogelin, L. 2013. The place of veneration in early Southeast Asian Buddhism, in S. Tarlow and L. Nilsson Stutz (eds) The Oxford Handbook of Death and Burial, 227-40, Oxford: Oxford University Press

GardeŁa, L. 2016. Worshipping the dead. Viking Age cemeteries as cult sites, in M. Egeler (ed.) Germanische Kultorte. Vergleichende, historische und rezeptionsgeschichtliche Perspektiven. Münchner Nordistische Studien, 24, 169-205, München: Herbert Utz

Gibson, C. 2007. Minerva: an early Anglo-Saxon mixed-rite cemetery in Alwalton, Cambridgeshire, Anglo-Saxon Stud. Archaeol. Hist., 14, 238-350

Green, B., Rogerson, A. and White, S. G. 1987. The Anglo-Saxon Cemetery at Morning Thorpe, Norfolk, East Anglian Archaeol., 36, Volumes 1-2, Dereham: Norfolk Archaeological Unit 
Hamerow, H. 2012. Rural Settlements and Society in Anglo-Saxon England, Oxford: Oxford University Press

Hills, C. and Lucy, S. 2013. Spong Hill Part IX: Chronology and Synthesis, Cambridge: McDonald Institute

Hills, C., Penn, K. and Rickett, R. 1984. The Anglo-Saxon Cemetery at Spong Hill, North Elmham. Part III, Catalogue of Inhumations. East Anglian Archaeology, 21, Dereham: Norfolk Archaeological Unit

Hogarth, A. C. 1973. Structural features in Anglo-Saxon graves, Archaeol. J., 130, 104-19

Høilund Nielsen, K. 2009. Rituals to free the spirit - or what the cremation pyre told, in D. Sayer and H. Williams (eds) Mortuary Practices and Social Identities in the Middle Ages: Essays in Burial Archaeology in Honour of Heinrich Härke, 81-103, Exeter: University of Exeter Press

Kan, S. 1989. Symbolic Immortality. The Tlingit Potlatch of the Nineteenth Century, Washington D.C.: Smithsonian Symbolic Immortality. The Tlingit Potlatch of the Nineteenth Century

Kinsley, A., 1989. The Anglo-Saxon Cemetery at Millgate, Newark-on-Trent, Nottinghamshire, Nottingham: University of Nottingham

Leahy, K. 2007. 'Interrupting the Pots.' The Excavation of Cleatham Anglo-Saxon Cemetery, Counc. Brit. Archaeol. Res. Rep., 155, York: Council for British Archaeology

McKinley, J. 1994. The Anglo-Saxon Cemetery at Spong Hill, North Elmham. Part VII: The Cremations, East Anglian Archaeology, 69, Dereham: Norfolk Archaeological Unit

McKinley, J. 2003. The Early Saxon cemetery at Park Lane, Croydon, Surrey Archaeol. Coll., 90, 1-116

McKinley, J. 2015. Cremated human bone and aspects of the cremation rite, in Egging Dinwiddy and Stoodley, 92-100

Nugent, R. 2017. Two of a kind: conceptual similarities between cremation and inhumation in early Anglo-Saxon England, in J. I. Cerezo-Román, A. Wessman and H. Williams (eds) Cremation and the Archaeology of Death, Oxford: Oxford University Press

Nugent, R. and Williams, H. 2012. Sighted surfaces: ocular agency in early Anglo-Saxon cremation burials, in I. M. Back Danielsson, F. Fahlander and Y. Sjöstrand (eds), Encountering Images: Materialities, Perceptions, Relations, Stockholm Studies in Archaeology, 57, 187-208, Stockholm: Stockholm University, Stockholm

Ravn, M. 2003. Death Ritual and Germanic Social Structure, Oxford: Brit. Archaeol. Rep. Int. Ser., 1164 
Richards, J. D. 1987. The Significance of Form and Decoration of Anglo-Saxon Cremation Urns, Oxford: Brit. Archaeol. Rep. Brit. Ser., 166

Rishøj Pedersen, L. 1974/5. Religious activities during dry season among the Lao Song Dam, Thailand, Folk, 16-17, 345-81

Saunders, P. R., 1980. Saxon barrows excavated by General Pitt Rivers on Merrow Down, Guildford, Surrey Archaeol. Coll., 72, 69-75

Semple, S., 2011. Sacred spaces and places in pre-Christian and conversion period AngloSaxon England, in H. Hamerow, D. A. Hinton and S. Crawford (eds), The Oxford Handbook of Anglo-Saxon Archaeology, 742-63, Oxford: Oxford University Press, Oxford

Semple, S. and Williams, H. 2015. Landmarks for the dead: exploring Anglo-Saxon mortuary geographies, in M. Clegg Hyer and G. R. Owen-Crocker (eds) The Material Culture of the Built Environment in the Anglo-Saxon World, Vol. II of The Material Culture of Daily Living in the Anglo-Saxon World, 137-61, Liverpool: Liverpool University Press

Shephard, J. 1979. The social identity of the individual in isolated barrows and barrow cemeteries in Anglo-Saxon England, B. C. Burnham and J. Kingsbury (eds) Space, Hierarchy and Society, 47-80, Oxford: Brit. Archaeol. Rep. Brit. Ser, 59

Soffield, C. 2015. Living with the dead: human burials in Anglo-Saxon settlement contexts, Archaeol. J., 172, 351-88

Squires, K. E. 2012. Populating the pots: the demography of the Early Anglo-Saxon cemeteries at Elsham and Cleatham, North Lincolnshire, Archaeol. J., 169, 312-42

Squires, K. E. 2013. Piecing together identity: a social investigation of early Anglo-Saxon cremation practices, Archaeol. J., 170, 154-200

Squires, K. E. 2017. Come rain or shine? The social implications of seasonality and weather on the cremation rite in early Anglo-Saxon England, in J. I. Cerezo-Román, A. Wessman and $\mathrm{H}$. Williams (eds) Cremation and the Archaeology of Death, Oxford: Oxford University Press

Stoodley, N. 2015. Discussion of burial practices, in Egging Dinwiddy and Stoodley (eds), $138-56$

Timby, J. 1993. Sancton I Anglo-Saxon cemetery. Excavations carried out between 1976 and 1980, Archaeol. J., 150, 243-365

Tyler, S. and Major, H. 2005. The Early Anglo-Saxon Cemetery and Later Saxon Settlement at Springfield Lyons, Essex, East Anglian Archaeol., 111, Chelmsford: Essex County Council

Ucko, P. 1969. Ethnography and archaeological interpretation of funerary remain, World Archaeol., 1(2), 262-80 
Wessman, A. AND Williams, H. 2017. Building for the cremated dead, in J. I. Cerezo-Román, A. Wessman and H. Williams (eds) Cremation and the Archaeology of Death, Oxford: Oxford University Press

Williams, H. 1997. Ancient landscapes and the dead: the reuse of prehistoric and Roman monuments as early Anglo-Saxon burial sites, Medieval Archaeol., 41, 1-31

Williams, H. 2000. 'The Burnt Germans of the Age of Iron': An Analysis of Early AngloSaxon Cremation Practices, Unpublished Doctoral Thesis, Reading: University of Reading

Williams, H. 2002. "The remains of Pagan Saxondom"? Studying Anglo-Saxon cremation practices, in S. Lucy and A. Reynolds (eds) Burial in Early Medieval England and Wales, Soc. Medieval Archaeology Monogr. Ser., 17, 47-71, Leeds, Maney

Williams, H. 2004. Assembling the dead, in A. Pantos and S. Semple (eds) Assembly Places and Practices in Medieval Europe, 109-34, Dublin: Four Courts Press Dublin

Williams, H. 2006. Death and Memory in Early Medieval Britain, Cambridge: Cambridge University Press

Williams, H. 2007. Transforming body and soul: toilet implements in early Anglo-Saxon graves, in S. Semple and H. Williams (eds) Early Medieval Mortuary Practices: Anglo-Saxon Studies in Archaeology and History, 14, 66-91

Williams, H. 2011a. Mortuary practices in early Anglo-Saxon England, in H. Hamerow, D. Hinton and S. Crawford (eds), The Oxford Handbook of Anglo-Saxon Archaeology, 238-59

Williams, H. 2011b. The sense of being seen: ocular effects at Sutton Hoo, J. Social Archaeol., 11(1), 99-121

Williams, H. 2014. A well-urned rest: cremation and inhumation in early Anglo-Saxon England, in I. Kuijt, C. P. Quinn and G. Cooney (eds) Transformation by Fire: The Archaeology of Cremation in Cultural Context, 93-118, Tucson: University of Arizona Press

Williams, H. 2015a. Towards an archaeology of cremation, in C. W. Schmidt and S. Symes (eds) The Analysis of Burned Human Remains, 2nd Edition, 259-93, London: Academic Press mortuary houses in early anglo-saxon england 31

Williams, H. 2015b. Death, hair and memory: cremation's heterogeneity in early AngloSaxon England, Analecta Archaeologica Ressoviensia, 10, 29-76

Williams, H. 2016. Ethnographies for early Anglo-Saxon cremation, in I. Riddler, J. Soulat and L. Keys (eds) The Evidence of Material Culture: Studies in Honour of Professor Vera Evison, 139-54, Autun: Éditons Mergoil 
Williams, H., Cerezo-Román, J. I. and Wessman, A. (eds) 2017. Introduction: Archaeologies of Cremation, in J. I. Cerezo-Román, A. Wessman and H. Williams (eds) Cremation and the Archaeology of Death, 1-24, Oxford: Oxford University Press

Yoe, S. 1896. The Burman: His Life and Notions, London: MacMillan

Zgusta, R. 2015. The Peoples of Northeast Asia through Time, Koninklijke: Brill 